\title{
Implementation of the National Health Insurance Scheme (NHIS) in Ghana: Lessons for South Africa and Low- and Middle-Income Countries
}

This article was published in the following Dove Press journal: Risk Management and Healthcare Policy

\author{
Christmal Dela Christmals (iD) \\ Kizito Aidam (iD) ${ }^{2}$ \\ 'Research on the Health Workforce for \\ Equity and Quality, Centre for Health \\ Policy, School of Public Health, University \\ of Witwatersrand, Johannesburg, South \\ Africa; ${ }^{2}$ Department of Bacteriology, \\ Noguchi Memorial Institute for Medical \\ Research, University of Ghana, Accra, \\ Ghana
}

Background: South Africa is having difficulties in rolling out the National Health Insurance (NHI) policy. There are ongoing arguments on whether the NHI will provide access to quality and equitable healthcare it is intended to and whether South Africa is ready to implement the policy. Many stakeholders believe the country needs more preparation if the policy will be successful. Ghana, on the other hand, has successfully implemented the National Health Insurance Scheme(NHIS) for over 15 years.

Objective: This paper sought to explore the implementation of the NHIS in Ghana and the lessons South Africa and other low- and middle-income countries can learn from such a process. Methods: A scoping review was conducted using the Joanna Brigs Institute's System for the Unified Management, Assessment and Review of Information (SUMARI) and Mendeley reference manager to manage the review process. Journal articles published on the NHIS in Ghana from January 2003 to December 2018 were searched from Science Direct, PubMed, Scopus, CINAHL, and Medline using the keywords: Ghana, Health, and Insurance.

Results: The implementation of the NHIS has provided access to healthcare for the Ghanaian population, especially to poor and vulnerable . Despite the successful implementation of the NHIS in Ghana, the scheme is challenged with poor coverage; poor quality of care; corruption and ineffective governance; poor stakeholder participation; lack of clarity on concepts in the policy; intense political influence; and poor financing.

Conclusion: The marked inequity in the South African health system makes the implementation of the NHI inevitable. The challenges experienced in the implementation of the NHIS in Ghana are not new to the South African healthcare system. South Africa must learn from the experiences of Ghana,a context that shares common socio-cultural and economic factors and disease burden,in order to successfully implement the NHI.

Keywords: national health insurance, universal health coverage, Ghana, South Africa, lower-middle income countries, sub-Saharan Africa

\section{Introduction}

National Health Insurance (NHI) is the lifeblood of Universal Health Coverage (UHC) globally, especially in sub-Saharan Africa. ${ }^{1,2}$ Many advanced nations have implemented various modifications of the Beveridge, Bismarck, or private health insurance models. ${ }^{3}$ In sub-Saharan African countries such as Ghana, Kenya, Nigeria, Tanzania, and Uganda, different forms of health insurance were observed. These health insurances are primarily community-based. ${ }^{4-6}$

In Ghana, the National Health Insurance Scheme (NHIS) was established in August 2003 to promote access to equitable and quality healthcare for all citizens,
Correspondence: Christmal Dela Christmals

Research on the Health Workforce for Equity and Quality, Centre for Health Policy, School of Public Health, University of Witwatersrand, South Africa

Email christmal.christmals@wits.ac.za

Risk Management and Healthcare Policy 2020:13 1879-1904 
irrespective of the individual's socio-economic features. ${ }^{7}$ The National Health Insurance Authority (NHIA) governs the scheme. The National Health Insurance Fund (NHIF), as stipulated in Act 650 of 2003, was set up to fund the healthcare of Ghanaians. ${ }^{7}$ The NHIF generates its cash inflow from five sources including $2.5 \%$ of the $17.5 \%$ Value-Added Tax (VAT), $2.5 \%$ of the $17.5 \%$ Social Security and National Insurance Trust (SSNIT) from formal sector employees, dividends of investments made by the NHIA, donations, and premiums paid by scheme subscribers. ${ }^{8,9}$ The scheme provides premium exemptions for the elderly (70 years and above), SSNIT pensioners, children below 18 years, pregnant women, and the beneficiaries of the Livelihood Empowerment Against Poverty (LEAP) - a pro-poor social intervention carried out by the central government. ${ }^{10}$ The insurance scheme covers $95 \%$ of the burden of diseases in Ghana. ${ }^{10}$ Services covered by the scheme include out-patient services, in-patient services, maternity care, eye care, and oral healthcare services. $^{10}$

At the inception of the NHIS, the payment of healthcare providers was through itemized fee-for-service. However, in 2008, the Ghana Diagnostic Related Groupings (G-DRGs) for services and fee-for-service for medicines at all levels of service delivery was introduced in a reform. Under this system, the NHIS District/Municipal/Metropolitan offices engage the various NHIS certified health facilities on a contract basis. The health facilities then provide services for the NHIS subscribers and submit claims for services rendered to the NHIS District/Municipal/Metropolitan offices for reimbursement. ${ }^{11}$

Like any other policy, the implementation of the NHIS achieved some successes but had challenges. South Africa is having difficulties in rolling out the NHI policy. There are ongoing arguments on whether the NHI will produce the access, equity, and quality healthcare it is intended to, and whether South Africa is ready to implement the policy. ${ }^{12}$ Many stakeholders believe the country needs more preparation if the policy will be successful. ${ }^{13}$ Ghana, on the other hand, has successfully implemented the NHIS for over 15 years. South Africa and other countries with similar geography, disease burden, economic grouping, and sociocultural context could learn from the successes and the challenges of Ghana in developing National Health Insurance and Universal Health Coverage funding models for low- and middle-income countries.

\section{Aim}

This scoping review sought to explore the 15 years of implementation of the NHIS in Ghana and the lessons South Africa and other low- and middle-income countries can learn from such a process.

\section{Design}

A scoping review is either a pre-systematic review or a standalone review that seeks to map the breadth and depth of evidence in a field of study. ${ }^{14,15}$ This scoping review was conducted using the Joanna Brigs Institute's (JBI) System for the Unified Management, Assessment, and Review of Information (SUMARI) and Mendeley reference manager to manage the review process. ${ }^{16}$ The scoping review method was chosen because it better synthesizes findings from both the positivist and the constructivist paradigms than other review methods. ${ }^{17}$ The JBI SUMARI provides a computerized framework for the reviewers to follow in conducting the review.

\section{Search and Inclusion}

Journal articles published on the NHIS in Ghana from January 2003 to December 2018 were searched from Science Direct, PubMed, Scopus, CINAHL, and Medline using the keywords; Ghana, Health, and Insurance. The search terms used were made broad so as to find approximately all studies on the National Health Insurance Scheme of Ghana over the 15 years. The PCC criteria, representing Population of interest $(\mathrm{P})$, Concept $(\mathrm{C})$, and the Context $(\mathrm{C})$ guided the inclusion of studies in this review.

- The population of interest (P): represents all institutions and individuals involved in the implementation of the National Health Insurance Scheme in Ghana.

- The Concept (C): is the Implementation of the National Health Insurance Scheme.

- Context (C): represents the healthcare system of Ghana.

The review question, "how was the National Health Insurance Scheme implemented in Ghana" guided the scoping review. Studies were included if they were full journal articles published in English, written on the implementation of the National Health Insurance Scheme of Ghana from January 2003 to December 2018. 


\section{Critical Appraisal}

The JBI evidence-based critical appraisal tools were used by three JBI trained reviewers to appraise the studies included in this study. . A minimum of two recommendations were necessary for inclusion. A study was included if it met $80 \%$ of the quality criteria set by the appraisal tool. All full-text articles appraised were included.

\section{Data Collection}

The second author extracted the findings from all studies included onto the SUMARI page for this review. The findings extracted onto the SUMARI were reviewed by the first author to ensure it was accurate. The finalized data extraction sheet is presented in a data matrix (Table 1).

\section{Data Synthesis}

Quantitative data were transformed through a qualitizing process then synthesized with the qualitative data using a convergent integrated approach. ${ }^{18,19}$ The assessment of the certainty of the evidence from the studies was not done due to the complexity of recommendations from studies included and the quantitative data transformation process. Also, this was a scoping review, and the reviewers did not seek to compare phenomena and make judgments, hence the exclusion of assessment of certainty. The review process and the results were reported according to the PRISMA Extension for Scoping Reviews (PRISMA-ScR) reporting checklist. ${ }^{20}$ The findings extracted on the data matrix were coded independently by the two reviewers, and the codes were compared and discussed for intercoder agreement. The codes were refined based on the intercoder agreement for final coding. Similar codes were combined into sub-themes and related sub-themes into themes, as presented in the Results section.

\section{Results}

Seventy-seven of the 418 studies found on the NHIS were included (Figure 1). Figure 2 shows the trend of publications from the year of inception until December 2018 There were no empirical studies published within the first 4 years (2003-2006) of the implementation stage. Studies increased from 2007 to 2012, decreased from 2012 to 2015, then recorded a sharp rise in 2016, which remained constant in 2017 and then sharply decreased in 2018. Generally, the trend line shows a steady increase in publications from the inception of the scheme in 2003 to December 2018. The findings from the studies included in the review were synthesized below.

\section{Clarity of Policy}

Social policy affects the total population. The National Health Insurance policy is written in English only. Even the academics are seeking clarification on the content of the policy. ${ }^{4,21}$ Aryeetey et $\mathrm{al}^{22}$ discovered that the users do not understand the concept of poverty as stated in the NHIS document. Also Agyei-Baffour et $\mathrm{al}^{23}$ found that some Ghanaians do not fully understand the premium payment concepts though they hear of them. Researchers are advocating for a white paper that clearly defines the major concepts, comprehensive stakeholder engagement, and public education on the NHIS policy document. ${ }^{4,21}$

\section{Coverage}

The NHIS has made care accessible and affordable in Ghana. ${ }^{24-28}$ Some groups of people such as the aged, children, and pregnant women are given immunity against premium payment. ${ }^{28,29}$ This helped in removing some socio-economic barriers to healthcare. ${ }^{29,30}$ In terms of healthcare-seeking behavior, people who are registered in the scheme use healthcare services more than those who are not insured. ${ }^{30-33}$

Though the NHIS increased access to healthcare, this access is far from universal, as it demands premium payment before one can access healthcare. Many studies ${ }^{8,-32,-34-36}$ reported varying proportions of the population who are not covered by the scheme; a World Bank study ${ }^{7}$ reported that only $40 \%$ of the Ghanaian population were enrolled in the scheme by 2013. The actual figures and percentage of the population covered by the scheme from 2005 to 2017 are presented in Figure 3.

Though the scheme covers the major disease burden of the country, other services are not under the scheme. Many citizens are not eligible to access care because they are not enrolled in the scheme due to financial problems. The scheme is expected to protect Ghanaians against the cost of healthcare but it rather excludes the very poor, thereby increasing the financial burden on the poor. Ghanaians should not use the international definition of poverty as exemption criteria for premium payment as many local context variables are unique to the concept of poverty in Ghana. ${ }^{22,32,37}$ Fenny et $\mathrm{al}^{32}$ also suggested that the poor should be exempted from making insurance payments. The financial barriers need to be eliminated if the scheme is to fulfil the Universal Health Coverage mandate. ${ }^{26,-37-39}$ Asundep et $\mathrm{al}^{30}$ believe that minimizing the premium and increasing access is essential. The free maternal, child, and aged care policy is laudable 
Table I Data Matrix

\begin{tabular}{|c|c|c|c|c|c|}
\hline No. & $\begin{array}{l}\text { Author, } \\
\text { Date }\end{array}$ & Purpose of the Study & Methodology & Sample & $\begin{array}{l}\text { Key Findings and } \\
\text { Recommendations }\end{array}$ \\
\hline & \multicolumn{5}{|c|}{ Qualitative Studies } \\
\hline I. & $\begin{array}{l}\text { Abiiro \& } \\
\text { Mclntyre, } \\
2013^{21}\end{array}$ & $\begin{array}{l}\text { To examine the feasibility of one- } \\
\text { time premium payment for the } \\
\text { NHIS from stakeholders } \\
\text { perspective }\end{array}$ & $\begin{array}{l}\text { A combination of review of } \\
\text { publications, and focus } \\
\text { group discussion and key } \\
\text { informant interviews }\end{array}$ & $\begin{array}{l}28 \text { key informant } \\
\text { interviews, and } 2 \\
\text { FGD }\end{array}$ & $\begin{array}{l}\text { There is not enough clarity about } \\
\text { definition of one-time premium } \\
\text { and its modus operandi. A } \\
\text { whitepaper clearly spelling out } \\
\text { the modalities of the proposed } \\
\text { policy change is required. }\end{array}$ \\
\hline 2. & $\begin{array}{l}\text { Aboagye } \\
\text { et al, } 2017^{74}\end{array}$ & $\begin{array}{l}\text { To evaluate the NHIS using the } \\
\text { views of local community } \\
\text { members }\end{array}$ & $\begin{array}{l}\text { Qualitative study using in- } \\
\text { depth interviews and focus } \\
\text { group discussions }\end{array}$ & $\begin{array}{l}9 \text { key informants } \\
\text { and } 72 \text { FGD } \\
\text { members }\end{array}$ & $\begin{array}{l}\text { Lack of proper community } \\
\text { participation in the NHIS } \\
\text { decision-making process } \\
\text { The NHIS is not the pro-poor } \\
\text { intervention it was intended to } \\
\text { be. Stakeholder consultations } \\
\text { with community members to } \\
\text { improve enrolment }\end{array}$ \\
\hline 3. & $\begin{array}{l}\text { Adei et al, } \\
2012^{34}\end{array}$ & $\begin{array}{l}\text { To evaluate the implementation } \\
\text { of the NHIS }\end{array}$ & $\begin{array}{l}\text { Qualitative study using } \\
\text { interviews, and analysis of } \\
\text { secondary data from the } \\
\text { Kwabre East district } \\
\text { directorate }\end{array}$ & $\begin{array}{l}12 \text { interviews, and } \\
862 \text { persons from } \\
203 \text { households }\end{array}$ & $\begin{array}{l}\text { Majority of the citizens are not } \\
\text { registered unto the scheme } \\
\text { The scheme is under financial } \\
\text { stress due to high rates of non- } \\
\text { renewal of insurance. } \\
\text { Government should consider } \\
\text { implementing the one time } \\
\text { premium payment }\end{array}$ \\
\hline 4. & $\begin{array}{l}\text { Agyepong \& } \\
\text { Adjei, } \\
2008^{78}\end{array}$ & $\begin{array}{l}\text { To analyse the formation and } \\
\text { execution of the NHIS }\end{array}$ & $\begin{array}{l}\text { Qualitative case study } \\
\text { involving a combination of } \\
\text { review of secondary } \\
\text { literature, and participant } \\
\text { observation }\end{array}$ & & $\begin{array}{l}\text { Political goals and political actors } \\
\text { played a dominant role in the } \\
\text { policy process. Technical and } \\
\text { bureaucratic actors should be } \\
\text { given enhanced roles in the policy } \\
\text { process }\end{array}$ \\
\hline 5. & $\begin{array}{l}\text { Aryeetey } \\
\text { et al, } 2013^{22}\end{array}$ & $\begin{array}{l}\text { To compare community's } \\
\text { contextual definition of poverty } \\
\text { to the insurance pro-poor } \\
\text { payment policies }\end{array}$ & $\begin{array}{l}\text { Qualitative, using in-depth } \\
\text { interviews }\end{array}$ & 92 key informants & $\begin{array}{l}\text { Community's understanding of } \\
\text { poverty was based on common } \\
\text { socio-economic indicators. } \\
\text { Attention should be paid to the } \\
\text { local context in setting guidelines } \\
\text { on poverty related exemptions of } \\
\text { the NHIS }\end{array}$ \\
\hline 6. & $\begin{array}{l}\text { Ashigbie } \\
\text { et al, } 2016^{24}\end{array}$ & $\begin{array}{l}\text { To study the barriers to } \\
\text { procuring and disbursing medical } \\
\text { logistics under the NHIS }\end{array}$ & $\begin{array}{l}\text { Qualitative study using in- } \\
\text { depth interview and } \\
\text { checklist }\end{array}$ & $\begin{array}{l}26 \text { key informant } \\
\text { interviews }\end{array}$ & $\begin{array}{l}\text { NHIS has increased access to } \\
\text { healthcare. Barriers to the } \\
\text { scheme are mostly administrative } \\
\text { in nature. The private sector is } \\
\text { less efficient in rendering care to } \\
\text { the insured. Systems are needed } \\
\text { in place to serve as checks and } \\
\text { balances }\end{array}$ \\
\hline
\end{tabular}

(Continued) 
Table I (Continued).

\begin{tabular}{|c|c|c|c|c|c|}
\hline No. & $\begin{array}{l}\text { Author, } \\
\text { Date }\end{array}$ & Purpose of the Study & Methodology & Sample & $\begin{array}{l}\text { Key Findings and } \\
\text { Recommendations }\end{array}$ \\
\hline 7. & $\begin{array}{l}\text { Awoonor- } \\
\text { Williams } \\
\text { et al, } 2016^{50}\end{array}$ & $\begin{array}{l}\text { To examine the disharmony } \\
\text { between the NHIS and primary } \\
\text { healthcare }\end{array}$ & $\begin{array}{l}\text { Qualitative using in-depth } \\
\text { interviews }\end{array}$ & $\begin{array}{l}56 \text { in-depth } \\
\text { interviews }\end{array}$ & $\begin{array}{l}\text { Key barrier to the } \\
\text { implementation of the NHIS is } \\
\text { delay in payments. The scheme is } \\
\text { focused on curative care, at the } \\
\text { expense of primary healthcare. } \\
\text { Primary healthcare centers lack } \\
\text { adequate resources to discharge } \\
\text { their services. Stakeholder } \\
\text { consultations are required to fill } \\
\text { observed gaps }\end{array}$ \\
\hline 8. & $\begin{array}{l}\text { Barimah \& } \\
\text { Mensah, } \\
2013^{25}\end{array}$ & $\begin{array}{l}\text { To gather the perspective of } \\
\text { stakeholders on the } \\
\text { implementation of the NHIS }\end{array}$ & $\begin{array}{l}\text { Data from focus group } \\
\text { discussions }\end{array}$ & II participants & $\begin{array}{l}\text { NHIS has made healthcare } \\
\text { services more affordable. There } \\
\text { is the need to uproot deceitful } \\
\text { practices that accompany the } \\
\text { NHIS through proper record } \\
\text { keeping. }\end{array}$ \\
\hline 9. & $\begin{array}{l}\text { Debpuur } \\
\text { et al, } 2015^{76}\end{array}$ & $\begin{array}{l}\text { To identify service user and } \\
\text { givers' practices that constitute } \\
\text { abuse, and how to control them }\end{array}$ & Qualitative study & $\begin{array}{l}\text { I4 focused group } \\
\text { discussion, and } 4 \\
\text { individual in depth } \\
\text { interviews }\end{array}$ & $\begin{array}{l}\text { Both users and providers } \\
\text { admitted engaging in fraudulent } \\
\text { activities. Moral hazard risk the } \\
\text { sustainability of the scheme, } \\
\text { therefore should be addressed }\end{array}$ \\
\hline 10. & $\begin{array}{l}\text { Fenny et al, } \\
2016^{80}\end{array}$ & $\begin{array}{l}\text { To measure causes of } \\
\text { subscription and re-subscription } \\
\text { unto the insurance scheme }\end{array}$ & $\begin{array}{l}\text { Qualitative study using } \\
\text { focus group discussions and } \\
\text { key informant interviews }\end{array}$ & $\begin{array}{l}40 \text { members of } \\
\text { FGD and } 46 \text { key } \\
\text { informants }\end{array}$ & $\begin{array}{l}\text { Causes of subscription and re- } \\
\text { subscription are community } \\
\text { related and administrative } \\
\text { related. Advocated for reforms } \\
\text { to expand coverage }\end{array}$ \\
\hline II. & $\begin{array}{l}\text { Fusheini, } \\
2016^{54}\end{array}$ & $\begin{array}{l}\text { To study the governmental and } \\
\text { financial challenges towards the } \\
\text { execution of the NHIS }\end{array}$ & $\begin{array}{l}\text { Qualitative study using in- } \\
\text { depth interviews }\end{array}$ & 33 participants & $\begin{array}{l}\text { Propaganda and external } \\
\text { meddling of political actors were } \\
\text { barriers identified. } \\
\text { Other factors include inadequate } \\
\text { premiums, poor monitoring and } \\
\text { evaluation, poor preventive } \\
\text { practices, and immunities for } \\
\text { large categories of persons. Good } \\
\text { political leadership and a review } \\
\text { of the NHIS policy was suggested }\end{array}$ \\
\hline 12. & $\begin{array}{l}\text { Fusheini } \\
\text { et al, } 2017^{79}\end{array}$ & $\begin{array}{l}\text { To assess the barriers to the } \\
\text { implementation of NHIS in four } \\
\text { districts }\end{array}$ & $\begin{array}{l}\text { Qualitative study using in- } \\
\text { depth interview }\end{array}$ & 33 participants & $\begin{array}{l}\text { Human resources as well as } \\
\text { structural and organizational } \\
\text { challenges were noted. Important } \\
\text { measures are necessary to ensure } \\
\text { sustainability of the scheme }\end{array}$ \\
\hline
\end{tabular}

(Continued) 
Table I (Continued).

\begin{tabular}{|c|c|c|c|c|c|}
\hline No. & $\begin{array}{l}\text { Author, } \\
\text { Date }\end{array}$ & Purpose of the Study & Methodology & Sample & $\begin{array}{l}\text { Key Findings and } \\
\text { Recommendations }\end{array}$ \\
\hline 13. & $\begin{array}{l}\text { Wedam \& } \\
\text { Sanyare, } \\
2017^{85}\end{array}$ & $\begin{array}{l}\text { To evaluate the theories } \\
\text { regarding financing the NHIS }\end{array}$ & $\begin{array}{l}\text { Analysis of secondary, and } \\
\text { primary data from } \\
\text { qualitative in-depth } \\
\text { interviews }\end{array}$ & 1007 sources & $\begin{array}{l}\text { Political figures are pre-occupied } \\
\text { with making political gains out of } \\
\text { the subject of financing the NHIS, } \\
\text { at the expense of the } \\
\text { development of the scheme. } \\
\text { Coordination among stakeholder } \\
\text { to determine the way forward on } \\
\text { the financing of the NHIS }\end{array}$ \\
\hline 14. & $\begin{array}{l}\text { Wireko \& } \\
\text { Beland, } \\
2017^{121}\end{array}$ & $\begin{array}{l}\text { To study why external actors } \\
\text { begun supporting the NHIS even } \\
\text { after initially resisting the idea }\end{array}$ & $\begin{array}{l}\text { Analysis of secondary data } \\
\text { from literature, and in- } \\
\text { depth interviews }\end{array}$ & 22 participants & $\begin{array}{l}\text { The early fruits borne by the } \\
\text { scheme changed the disposition } \\
\text { of external actors towards the } \\
\text { scheme. External actors are not } \\
\text { always more powerful than local } \\
\text { actors agenda setting }\end{array}$ \\
\hline 15. & $\begin{array}{l}\text { Witter \& } \\
\text { Garshong, } \\
2009^{44}\end{array}$ & $\begin{array}{l}\text { To evaluate the implementation } \\
\text { of the NHIS }\end{array}$ & $\begin{array}{l}\text { Analysis of secondary } \\
\text { literature, and in-depth } \\
\text { interviews }\end{array}$ & 54 key informants & $\begin{array}{l}\text { The scheme is predominantly } \\
\text { funded through taxes. Enrolment } \\
\text { increased in multiple folds since } \\
\text { its inception. Low renewal rates } \\
\text { puts financial stress on the } \\
\text { scheme. The scheme is biased } \\
\text { against the poor and rural } \\
\text { dwellers. The uninsured are } \\
\text { discriminated against in terms of } \\
\text { service provision. Questions } \\
\text { remain over accountability of the } \\
\text { scheme }\end{array}$ \\
\hline 16. & $\begin{array}{l}\text { Witter et al, } \\
2007^{53}\end{array}$ & $\begin{array}{l}\text { To evaluate the operation of } \\
\text { payment immunities under the } \\
\text { NHIS }\end{array}$ & $\begin{array}{l}\text { Qualitative using in-depth } \\
\text { interviews }\end{array}$ & 65 informants & $\begin{array}{l}\text { The policy on payments } \\
\text { immunities for pregnant mothers } \\
\text { is a welcomed idea } \\
\text { However, financial challenges put } \\
\text { in doubt its sustainability. Proper } \\
\text { financing mechanisms should be } \\
\text { implemented }\end{array}$ \\
\hline 17. & $\begin{array}{l}\text { Yevutsey \& } \\
\text { Aikins, } \\
2010^{46}\end{array}$ & $\begin{array}{l}\text { To examine the economic } \\
\text { sustainability of the scheme in } \\
\text { two districts in the Upper East } \\
\text { region }\end{array}$ & $\begin{array}{l}\text { Secondary analysis of } \\
\text { district financial reports }\end{array}$ & $\begin{array}{l}\text { Revenue and } \\
\text { expenditure } \\
\text { reports from } 2004 \\
\text { to } 2007\end{array}$ & $\begin{array}{l}\text { Operations are mainly funded by } \\
\text { the insurance agency, and } \\
\text { payments made by subscribers. } \\
\text { The insurance agency should } \\
\text { make prompt payments to } \\
\text { facilities }\end{array}$ \\
\hline & \multicolumn{5}{|c|}{ Quantitative Studies } \\
\hline I. & $\begin{array}{l}\text { Abrokwah } \\
\text { et al, } \\
2017^{122}\end{array}$ & $\begin{array}{l}\text { To describe the connection } \\
\text { between health choices and } \\
\text { insurance status }\end{array}$ & $\begin{array}{l}\text { Analysis of secondary data } \\
\text { from the Ghana living } \\
\text { standards survey }\end{array}$ & $\begin{array}{l}106,577 \text { patient } \\
\text { records }\end{array}$ & $\begin{array}{l}\text { Insurance increase use of } \\
\text { biomedical care facilities. } \\
\text { Insurance protects against health } \\
\text { financial burden. Expansion of the } \\
\text { scheme was mooted }\end{array}$ \\
\hline
\end{tabular}

(Continued) 
Table I (Continued).

\begin{tabular}{|c|c|c|c|c|c|}
\hline No. & $\begin{array}{l}\text { Author, } \\
\text { Date }\end{array}$ & Purpose of the Study & Methodology & Sample & $\begin{array}{l}\text { Key Findings and } \\
\text { Recommendations }\end{array}$ \\
\hline 2. & $\begin{array}{l}\text { Abrokwah } \\
\text { et al, } \\
2014^{123}\end{array}$ & $\begin{array}{l}\text { To understand the impact of } \\
\text { NHIS on antenatal care }\end{array}$ & $\begin{array}{l}\text { Analysis of secondary data } \\
\text { from the Ghana Living } \\
\text { Standards Survey }\end{array}$ & 1012 records & $\begin{array}{l}\text { The insured have good health } \\
\text { seeking behaviour. } \\
\text { The insured have increased } \\
\text { accessibility to antenatal health } \\
\text { care. } \\
\text { The insured were protected } \\
\text { against health financial cost }\end{array}$ \\
\hline 3. & $\begin{array}{l}\text { Abuosi } \\
\text { et al, } \\
2016^{124}\end{array}$ & $\begin{array}{l}\text { To measure views on quality of } \\
\text { care between the insured and } \\
\text { uninsured }\end{array}$ & Cross-sectional survey & 818 participants & $\begin{array}{l}\text { No significant differences } \\
\text { between the views of insured and } \\
\text { uninsured patients on the quality } \\
\text { of care. The insured believed that } \\
\text { care was more affordable to } \\
\text { them. Level of quality of care } \\
\text { should be raised in the hospitals }\end{array}$ \\
\hline 4. & $\begin{array}{l}\text { Addae- } \\
\text { Korankye, } \\
2013^{38}\end{array}$ & $\begin{array}{l}\text { To evaluate the economic } \\
\text { barriers towards the } \\
\text { implementation of the NHIS }\end{array}$ & $\begin{array}{l}\text { Primary data (cross- } \\
\text { sectional study), and } \\
\text { analysis of secondary } \\
\text { literature }\end{array}$ & $\begin{array}{l}250 \text { primary } \\
\text { respondents }\end{array}$ & $\begin{array}{l}\text { There is inadequate funding for } \\
\text { the NHIS. Government should } \\
\text { enact a legislation making } \\
\text { registration unto the scheme } \\
\text { mandatory, and rich people } \\
\text { should pay higher premiums }\end{array}$ \\
\hline 5. & $\begin{array}{l}\text { Adomah- } \\
\text { Afari \& } \\
\text { Chandler, } \\
2018^{83}\end{array}$ & $\begin{array}{l}\text { To study the duties of national } \\
\text { and local stakeholders in } \\
\text { expanding and maintaining the } \\
\text { NHIS }\end{array}$ & $\begin{array}{l}\text { Analysis of secondary and } \\
\text { primary data }\end{array}$ & $\begin{array}{l}48 \text { males and } 50 \\
\text { females between } \\
18 \text { and } 70 \text { years, } \\
\text { and } 30 \text { peer } \\
\text { reviewed articles }\end{array}$ & $\begin{array}{l}\text { The NHIS will be effective when } \\
\text { central policies are } \\
\text { complemented with stakeholder } \\
\text { consultation at the local level. } \\
\text { State and local players should } \\
\text { work hand-in-hand to secure the } \\
\text { future of the scheme }\end{array}$ \\
\hline 6. & $\begin{array}{l}\text { Agyei- } \\
\text { Baffour } \\
\text { et al, } 2013^{23}\end{array}$ & $\begin{array}{l}\text { To gain insight into the awareness } \\
\text { and attitude of clients towards } \\
\text { the capitation system }\end{array}$ & Cross-sectional survey & $\begin{array}{l}422 \mathrm{NHIS} \\
\text { members }\end{array}$ & $\begin{array}{l}\text { A landslide of respondent heard } \\
\text { of the new capitation system, but } \\
\text { could not demonstrate an } \\
\text { understanding of the concept in } \\
\text { itself. Majority of the respondents } \\
\text { viewed capitation as a useless } \\
\text { innovation. Educational exercises } \\
\text { to increase knowledge on } \\
\text { capitation should be carried out }\end{array}$ \\
\hline 7. & $\begin{array}{l}\text { Agyemang } \\
\text { et al, } 2013^{64}\end{array}$ & $\begin{array}{l}\text { To outline the successes and } \\
\text { threats to the NHIS }\end{array}$ & $\begin{array}{l}\text { Combination of primary } \\
\text { data, and analysis of } \\
\text { secondary data (review of } \\
\text { annual and quarterly } \\
\text { reports) }\end{array}$ & 130 respondents & $\begin{array}{l}\text { Insurance increased access to } \\
\text { health. Insurance reduced risky } \\
\text { health behaviors, such as self- } \\
\text { medication. Threats to the NHIS } \\
\text { should be aptly resolved }\end{array}$ \\
\hline 8. & $\begin{array}{l}\text { Akazili et al, } \\
2017^{37}\end{array}$ & $\begin{array}{l}\text { To understand the economic } \\
\text { stress that point-of-service } \\
\text { payments inflicted in the pre- } \\
\text { NHIS age }\end{array}$ & $\begin{array}{l}\text { Analysis of secondary data } \\
\text { from the Ghana Living } \\
\text { Standard Survey } 5\end{array}$ & 36,488 individuals & $\begin{array}{l}\text { Point-of-service payments led to } \\
\text { a significant level of poverty in } \\
\text { households. } \\
\text { Poor should be protected from } \\
\text { health-related financial risks }\end{array}$ \\
\hline
\end{tabular}

(Continued) 
Table I (Continued).

\begin{tabular}{|c|c|c|c|c|c|}
\hline No. & $\begin{array}{l}\text { Author, } \\
\text { Date }\end{array}$ & Purpose of the Study & Methodology & Sample & $\begin{array}{l}\text { Key Findings and } \\
\text { Recommendations }\end{array}$ \\
\hline 9. & $\begin{array}{l}\text { Alhassan } \\
\text { et al, } \\
2015^{110}\end{array}$ & $\begin{array}{l}\text { To explore the attitude of } \\
\text { providers and consumers } \\
\text { towards quality in healthcare }\end{array}$ & Cross-sectional survey & $\begin{array}{l}1903 \text { households } \\
\text { and } 324 \text { health } \\
\text { staff }\end{array}$ & $\begin{array}{l}\text { Perception of providers and } \\
\text { consumers showed an inverse } \\
\text { relationship between technical } \\
\text { quality and quality of service. } \\
\text { Efforts should be carried out to } \\
\text { increase consumer confidence in } \\
\text { technical qualities of health } \\
\text { personnel }\end{array}$ \\
\hline 10. & $\begin{array}{l}\text { Alhassan } \\
\text { et al, } 2014^{56}\end{array}$ & $\begin{array}{l}\text { To assess the quality of } \\
\text { healthcare rendered by NHIS } \\
\text { institutions in the Wa } \\
\text { Municipality }\end{array}$ & Cross-sectional survey & 398 participants & $\begin{array}{l}\text { The consumer level of } \\
\text { satisfaction on the NHIS is below } \\
\text { average. NHIS services should be } \\
\text { improved }\end{array}$ \\
\hline 11. & $\begin{array}{l}\text { Alhassan } \\
\text { et al, } 2015^{55}\end{array}$ & $\begin{array}{l}\text { To gauge the quality of services } \\
\text { rendered by NHIS qualified } \\
\text { facilities }\end{array}$ & Cross-sectional survey & 64 facilities & $\begin{array}{l}\text { One third of the facilities deliver } \\
\text { efficient services. Public facilities } \\
\text { deliver more efficient services } \\
\text { than private and mission facilities. } \\
\text { Rural facilities had the higher } \\
\text { chances of being more } \\
\text { competent. Stakeholders should } \\
\text { take steps to exterminate waste } \\
\text { from the system }\end{array}$ \\
\hline 12. & $\begin{array}{l}\text { Alhassan } \\
\text { et al, } 2016^{51}\end{array}$ & $\begin{array}{l}\text { To compare the opinion of health } \\
\text { professionals on the NHIS before } \\
\text { and after community } \\
\text { intervention }\end{array}$ & Randomized cluster trial & $\begin{array}{l}234 \text { health } \\
\text { professionals }\end{array}$ & $\begin{array}{l}\text { Health providers noted late } \\
\text { reimbursement as a key barrier } \\
\text { to the NHIS. Community and } \\
\text { stakeholder consultations are } \\
\text { necessary in the growth of the } \\
\text { scheme }\end{array}$ \\
\hline 13. & $\begin{array}{l}\text { Apanga } \\
\text { et al, } \\
2014^{125}\end{array}$ & $\begin{array}{l}\text { To investigate the financial } \\
\text { consequences of drugs } \\
\text { overbilling under the NHIS }\end{array}$ & $\begin{array}{l}\text { Retrospective cross- } \\
\text { sectional study }\end{array}$ & $\begin{array}{l}4238 \\
\text { reimbursement } \\
\text { requests }\end{array}$ & $\begin{array}{l}\text { The difference in average cost of } \\
\text { drugs and antibiotics was } \\
\text { significantly higher in private } \\
\text { health facilities than the public } \\
\text { ones. WHO recommendation on } \\
\text { optimal prescription should be } \\
\text { used }\end{array}$ \\
\hline 14. & $\begin{array}{l}\text { Aryeetey } \\
\text { et al, } 2016^{42}\end{array}$ & $\begin{array}{l}\text { To analyse the effects of NHIS on } \\
\text { the service delivery of Christian } \\
\text { health facilities }\end{array}$ & $\begin{array}{l}\text { Retrospective cross- } \\
\text { sectional }\end{array}$ & 183 records & $\begin{array}{l}\text { Attitude towards service delivery } \\
\text { was positive. Both health revenue } \\
\text { and expenditure increased as a } \\
\text { result of NHIS. Default in terms } \\
\text { of payments remains a challenge. } \\
\text { Challenges should be addressed } \\
\text { to improve service delivery }\end{array}$ \\
\hline 15. & $\begin{array}{l}\text { Asibey \& } \\
\text { Agyemang, } \\
2017^{33}\end{array}$ & $\begin{array}{l}\text { To examine the relationship } \\
\text { between insurance status and } \\
\text { healthcare utilization rates in } \\
\text { rural Ghana }\end{array}$ & Cross-sectional survey & 286 participants & $\begin{array}{l}\text { Health seeking behavior was } \\
\text { poor. The insured significantly } \\
\text { had increased to healthcare. } \\
\text { NHIS should be expanded, } \\
\text { especially to the poor }\end{array}$ \\
\hline
\end{tabular}

(Continued) 
Table I (Continued).

\begin{tabular}{|c|c|c|c|c|c|}
\hline No. & $\begin{array}{l}\text { Author, } \\
\text { Date }\end{array}$ & Purpose of the Study & Methodology & Sample & $\begin{array}{l}\text { Key Findings and } \\
\text { Recommendations }\end{array}$ \\
\hline 16. & $\begin{array}{l}\text { Asundep } \\
\text { et al, } 2013^{60}\end{array}$ & $\begin{array}{l}\text { To study factors influencing } \\
\text { access to antenatal care, and } \\
\text { maternal health outcomes in } \\
\text { Kumasi }\end{array}$ & Cross-sectional study & $\begin{array}{l}643 \text { expectant } \\
\text { mothers }\end{array}$ & $\begin{array}{l}\text { About } 20 \% \text { of women } \\
\text { experienced adverse health } \\
\text { outcomes. Occurrence of } \\
\text { adverse health outcome was } \\
\text { associated with cost. Minimizing } \\
\text { cost of NHIS and increasing } \\
\text { accessibility should be a priority }\end{array}$ \\
\hline 17. & $\begin{array}{l}\text { Boateng \& } \\
\text { Awunyor- } \\
\text { Vitor, } \\
2013^{35}\end{array}$ & $\begin{array}{l}\text { To explore people's perception } \\
\text { on the insurance policy and } \\
\text { reasons why they renew upon } \\
\text { expiration }\end{array}$ & Cross-sectional survey & $\begin{array}{l}300, \text { consisting of } \\
204 \text { females, and } \\
96 \text { males }\end{array}$ & $\begin{array}{l}61.1 \% \text { of respondents were } \\
\text { enrolled in the NHIS, } 23.9 \% \text { had } \\
\text { not renewed their insurance after } \\
\text { enrolment and } 15 \% \text { had never } \\
\text { enrolled. Gender, marital status, } \\
\text { religion, and perception of health } \\
\text { status of respondents significantly } \\
\text { influenced their decision to } \\
\text { continue with the NHIS. } \\
\text { Awareness creation activities are } \\
\text { required to expand access to the } \\
\text { scheme }\end{array}$ \\
\hline 18. & $\begin{array}{l}\text { Boateng } \\
\text { et al, } 2017^{36}\end{array}$ & $\begin{array}{l}\text { To investigate the causes of NHIS } \\
\text { subscription, renewal, and } \\
\text { consumption }\end{array}$ & Cross-sectional survey & 392 female porters & $\begin{array}{l}\text { Age, socioeconomic status, and } \\
\text { quality of service lead to } \\
\text { registration, continuation, and } \\
\text { use of NHIS services. Long } \\
\text { waiting times is a disincentive } \\
\text { toregister. }\end{array}$ \\
\hline 19. & $\begin{array}{l}\text { Carapinha } \\
\text { et al, } 2011^{4}\end{array}$ & $\begin{array}{l}\text { To assess the policies on the } \\
\text { distribution of medicines in } \\
\text { Ghana, Tanzania, Kenya, Uganda, } \\
\text { and Nigeria }\end{array}$ & Cross-sectional survey & $\begin{array}{l}33 \text { health } \\
\text { insurance } \\
\text { programs }\end{array}$ & $\begin{array}{l}\text { Policies related to medicine is not } \\
\text { thoroughly clear. Stakeholders } \\
\text { should come together to provide } \\
\text { clarity on policies related to } \\
\text { distribution of medicines }\end{array}$ \\
\hline $\begin{array}{l}20 . \\
d\end{array}$ & $\begin{array}{l}\text { Dalaba et al, } \\
2014^{26}\end{array}$ & $\begin{array}{l}\text { To examine the financial } \\
\text { implication on malaria treatment }\end{array}$ & Cross-sectional survey & 4226 households & $\begin{array}{l}\text { The insured accessed malaria } \\
\text { treatment more than the } \\
\text { uninsured. Measures to increase } \\
\text { enrolment for the poor should be } \\
\text { sped up. }\end{array}$ \\
\hline 21. & $\begin{array}{l}\text { Dalinjong } \\
\text { et al, } 2017^{31}\end{array}$ & $\begin{array}{l}\text { To investigate the connection } \\
\text { between insurance registration } \\
\text { and use of healthcare services in } \\
\text { rural areas of Northern Ghana }\end{array}$ & Cross-sectional survey & 55,992 individuals & $\begin{array}{l}\text { The insured significantly used } \\
\text { health services more. Those with } \\
\text { chronic health conditions and the } \\
\text { poor used health services more. } \\
\text { The poor mostly used } \\
\text { community health centee, whilst } \\
\text { the rich and the uninsured mostly } \\
\text { patronized public hospitals and } \\
\text { private centers, respectively. } \\
\text { Sustenance of the NHIS is crucial. }\end{array}$ \\
\hline
\end{tabular}

(Continued) 
Table I (Continued).

\begin{tabular}{|c|c|c|c|c|c|}
\hline No. & $\begin{array}{l}\text { Author, } \\
\text { Date }\end{array}$ & Purpose of the Study & Methodology & Sample & $\begin{array}{l}\text { Key Findings and } \\
\text { Recommendations }\end{array}$ \\
\hline 22. & $\begin{array}{l}\text { Dixon et al, } \\
2013^{59}\end{array}$ & $\begin{array}{l}\text { To investigate members' views on } \\
\text { the services of the NHIS }\end{array}$ & $\begin{array}{l}\text { Secondary data from the } \\
2008 \text { national demographic } \\
\text { and health survey }\end{array}$ & $\begin{array}{l}\text { Males } 1422 ; \\
\text { females } 2046\end{array}$ & $\begin{array}{l}\text { Wealthy men perceive the } \\
\text { services of the scheme as inferior } \\
\text { to that of other means, however, } \\
\text { wealthy women do not perceive } \\
\text { the services of the scheme to be } \\
\text { inferior to other alternatives. } \\
\text { Akan women are more likely to } \\
\text { view services of the scheme as } \\
\text { either better or at the same level } \\
\text { with other alternatives. Views of } \\
\text { service users on the scheme is } \\
\text { important in ensuring its } \\
\text { sustainability }\end{array}$ \\
\hline 23. & $\begin{array}{l}\text { Duku et all, } \\
2016^{49}\end{array}$ & $\begin{array}{l}\text { To measure lifetime and current } \\
\text { prevalence of NHIS registration }\end{array}$ & $\begin{array}{l}\text { Analysis of secondary data } \\
\text { from NHIS records }\end{array}$ & $9,408,819$ entries & $\begin{array}{l}\text { The probability of re-registering } \\
\text { is proportion the use of } \\
\text { healthcare. Compulsory } \\
\text { enrolment should be } \\
\text { implemented }\end{array}$ \\
\hline 24. & $\begin{array}{l}\text { Duku et al, } \\
2018^{11}\end{array}$ & $\begin{array}{l}\text { To determine if insurance status } \\
\text { has any effect on people's views } \\
\text { on quality of care }\end{array}$ & Cross-sectional survey & $\begin{array}{l}1903 \text { household } \\
\text { heads }\end{array}$ & $\begin{array}{l}\text { Enrolled people has worse views } \\
\text { on quality of healthcare as } \\
\text { compared to the un-enrolled. } \\
\text { Policy-makers should make the } \\
\text { care given to the insured more } \\
\text { attractive }\end{array}$ \\
\hline 25. & $\begin{array}{l}\text { Dzakpasu } \\
\text { et al, } 2012^{30}\end{array}$ & $\begin{array}{l}\text { To determine the relationship } \\
\text { between antenatal exemption } \\
\text { and skilled delivery, and } \\
\text { insurance coverage }\end{array}$ & Time series method & 92,467 & $\begin{array}{l}\text { There was a substantial increase } \\
\text { in the skilled attendance due to } \\
\text { free maternal health policy. There } \\
\text { was substantial increment in } \\
\text { insurance coverage } \\
\text { The poor benefited most from } \\
\text { the free maternal policy. There } \\
\text { should be a continuation of the } \\
\text { free maternal policy }\end{array}$ \\
\hline 26. & $\begin{array}{l}\text { Effah et al, } \\
2016^{81}\end{array}$ & $\begin{array}{l}\text { To evaluate the implementation } \\
\text { of the NHIS in the Juaboso } \\
\text { district }\end{array}$ & $\begin{array}{l}\text { Analysis of both secondary } \\
\text { and primary data }\end{array}$ & $\begin{array}{l}200 \text { primary } \\
\text { respondents }\end{array}$ & $\begin{array}{l}\text { Membership almost doubled in } \\
\text { the district within the time frame } \\
\text { of research. } \\
\text { Increment was observed in both } \\
\text { spending and income. } \\
\text { Accountability measures should } \\
\text { be put in place }\end{array}$ \\
\hline 27. & $\begin{array}{l}\text { Fenny et al, } \\
2014^{32}\end{array}$ & $\begin{array}{l}\text { To examine how insurance } \\
\text { enrolment affects healthcare } \\
\text { utilization }\end{array}$ & Cross-sectional survey & $\begin{array}{l}\text { II,089 individuals } \\
\text { from } 2430 \\
\text { households }\end{array}$ & $\begin{array}{l}\text { The insured are more likely to } \\
\text { report their health problems to a } \\
\text { formal health facility than the } \\
\text { uninsured. Insurance payments } \\
\text { are unfair towards the poor. } \\
\text { The poor should be exempted } \\
\text { from making insurance payments }\end{array}$ \\
\hline
\end{tabular}

(Continued) 
Table I (Continued).

\begin{tabular}{|c|c|c|c|c|c|}
\hline No. & $\begin{array}{l}\text { Author, } \\
\text { Date }\end{array}$ & Purpose of the Study & Methodology & Sample & $\begin{array}{l}\text { Key Findings and } \\
\text { Recommendations }\end{array}$ \\
\hline 28. & $\begin{array}{l}\text { (Fosu et al, } \\
2014^{27}\end{array}$ & $\begin{array}{l}\text { The effect of community } \\
\text { insurance on healthcare seeking } \\
\text { behavior }\end{array}$ & $\begin{array}{l}\text { Analysis of secondary data } \\
\text { from hospital archives }\end{array}$ & & $\begin{array}{l}\text { Insurance increased accessibility } \\
\text { to health. Community insurance } \\
\text { scheme can serve as a model for } \\
\text { national insurance scheme }\end{array}$ \\
\hline 29. & $\begin{array}{l}\text { Frimpong } \\
\text { et al, } 2014^{29}\end{array}$ & $\begin{array}{l}\text { To study the relationship } \\
\text { between perinatal immunities } \\
\text { and use of maternal health } \\
\text { services }\end{array}$ & Retrospective cohort study & $164 \mid$ women & $\begin{array}{l}\text { Premium immunities increased } \\
\text { access to insurance by women. } \\
\text { Biomedical services were used } \\
\text { more than ANC services. Unlike } \\
\text { community health compounds, } \\
\text { dominant proportions of women } \\
\text { who sought ANC services at } \\
\text { hospitals and health centers } \\
\text { delivered at this centers. Special } \\
\text { intervention aimed at improving } \\
\text { delivery at CHIPS centers for the } \\
\text { insured is advocated }\end{array}$ \\
\hline 30. & $\begin{array}{l}\text { Goudge } \\
\text { et al, } \\
2012^{126}\end{array}$ & $\begin{array}{l}\text { To measure the attitude of } \\
\text { Ghanaians, South Africans, and } \\
\text { Tanzanians on social financing } \\
\text { mechanism of national insurance } \\
\text { scheme }\end{array}$ & Analysis of secondary data & $\begin{array}{l}4800 \text { households } \\
\text { in SA, } 2986 \\
\text { households in } \\
\text { Ghana, and } 2234 \\
\text { households in } \\
\text { Tanzania }\end{array}$ & $\begin{array}{l}\text { Majority of the population in } \\
\text { Ghana and South Africa are } \\
\text { willing to cross-subsidize cost. } \\
\text { Less than half of the population in } \\
\text { Tanzania were willing to cross- } \\
\text { subsidize }\end{array}$ \\
\hline 31. & $\begin{array}{l}\text { Gyasi, } \\
2015^{66}\end{array}$ & $\begin{array}{l}\text { To investigate the impact NHIS } \\
\text { has on the use of unorthodox } \\
\text { medicine }\end{array}$ & $\begin{array}{l}\text { Retrospective cross- } \\
\text { sectional }\end{array}$ & 324 & $\begin{array}{l}\text { Use of traditional medicine was } \\
\text { high amongst both insured and } \\
\text { uninsured, but has no association } \\
\text { with insurance status. Traditional } \\
\text { medicines should be involved in } \\
\text { the NHIS }\end{array}$ \\
\hline 32. & $\begin{array}{l}\text { Ibrahim \& } \\
\text { O'Keefe, } \\
2014^{68}\end{array}$ & $\begin{array}{l}\text { To compare the differences in } \\
\text { birth outcomes during the out- } \\
\text { of-pocket and NHIS period }\end{array}$ & $\begin{array}{l}\text { Analysis of secondary data } \\
\text { from the Tamale Teaching } \\
\text { hospital }\end{array}$ & 7895 & $\begin{array}{l}\text { No significant difference was } \\
\text { observed in the birth of low birth } \\
\text { weight children between the two } \\
\text { periods }\end{array}$ \\
\hline 33. & $\begin{array}{l}\text { Ibrahim } \\
\text { et al, } 2016^{69}\end{array}$ & $\begin{array}{l}\text { To compare rates of perinatal } \\
\text { deaths between the health user } \\
\text { fees and NHIS ages }\end{array}$ & $\begin{array}{l}\text { Analysis of secondary birth } \\
\text { registry data from the } \\
\text { Tamale Teaching Hospital }\end{array}$ & 8312 & $\begin{array}{l}\text { The proportion of infant } \\
\text { mortality recorded in the health } \\
\text { user fees period was halved } \\
\text { during the insurance period. } \\
\text { More maternal mortality were } \\
\text { recorded in the pay-as-you-go } \\
\text { period for elderly mothers. More } \\
\text { cesarean sections were recorded } \\
\text { in the NHIS period. More } \\
\text { vulnerable groups should be } \\
\text { exempted from paying NHIS fees }\end{array}$ \\
\hline
\end{tabular}

(Continued) 
Table I (Continued).

\begin{tabular}{|c|c|c|c|c|c|}
\hline No. & $\begin{array}{l}\text { Author, } \\
\text { Date }\end{array}$ & Purpose of the Study & Methodology & Sample & $\begin{array}{l}\text { Key Findings and } \\
\text { Recommendations }\end{array}$ \\
\hline 34. & $\begin{array}{l}\text { Jehu-Appiah } \\
\text { et al, } 2012^{10}\end{array}$ & $\begin{array}{l}\text { To assess the marriage between } \\
\text { opinions on healthcare services, } \\
\text { and NHIS status }\end{array}$ & Cross-sectional survey & $\begin{array}{l}\text { I3,865 participants } \\
\text { from } 330 \text { I } \\
\text { households }\end{array}$ & $\begin{array}{l}\text { Decision to subscribe and renew } \\
\text { NHIS subscription is based on } \\
\text { usefulness, accessibility, and } \\
\text { affordability. Participants have } \\
\text { welcoming opinions on the } \\
\text { quality of services, its usefulness, } \\
\text { and accessibility. However, they } \\
\text { were cold towards posture of } \\
\text { providers, and pricing. The } \\
\text { insured were more dissatisfied } \\
\text { than the uninsured. Perceptions } \\
\text { should be addressed to increase } \\
\text { enrolment }\end{array}$ \\
\hline 35. & $\begin{array}{l}\text { (Jehu- } \\
\text { Appiah } \\
\text { et al, 201 }{ }^{41}\end{array}$ & $\begin{array}{l}\text { To determine fairness and } \\
\text { determinants of enrolment unto } \\
\text { the NHIS }\end{array}$ & Cross-sectional survey & $\begin{array}{l}\text { I3,865 participants } \\
\text { from } 330 \text { I } \\
\text { households }\end{array}$ & $\begin{array}{l}\text { The poor are marginalized in } \\
\text { terms of enrolment. There are } \\
\text { varying determinants influencing } \\
\text { both the poor and rich's decision } \\
\text { to enrol unto the scheme. High } \\
\text { premiums and lack of trust in the } \\
\text { scheme work against re- } \\
\text { subscription. Coverage should be } \\
\text { extended to the poor }\end{array}$ \\
\hline 36. & $\begin{array}{l}\text { Lambon,- } \\
\text { Quayefio \& } \\
\text { Owoo, } \\
2017^{70}\end{array}$ & $\begin{array}{l}\text { To effect the causes of health } \\
\text { insurance subscription, and its } \\
\text { impact on neonatal health }\end{array}$ & $\begin{array}{l}\text { Analysis of secondary data } \\
\text { from the Ghana } \\
\text { demographic and health } \\
\text { survey }\end{array}$ & I2,000 households & $\begin{array}{l}\text { Insurance significantly reduces } \\
\text { neonatal deaths. Residents in } \\
\text { urban areas are more prone to } \\
\text { neonatal death. Longer distances } \\
\text { to healthcare facility is a risk } \\
\text { factor of neonatal death. } \\
\text { Coverage should be increased for } \\
\text { mothers and neonates }\end{array}$ \\
\hline 37. & $\begin{array}{l}\text { Lamptey } \\
\text { et al, } 2017^{63}\end{array}$ & $\begin{array}{l}\text { To evaluate trend of NHIS } \\
\text { certification for private sector } \\
\text { healthcare providers }\end{array}$ & $\begin{array}{l}\text { A cross-sectional } \\
\text { quantitative analysis of } \\
\text { administrative data }\end{array}$ & 1600 records & $\begin{array}{l}\text { A great majority of the facilities } \\
\text { were NHIS certified. Majority of } \\
\text { the facilities marginally passed the } \\
\text { certification test. Private sector } \\
\text { healthcare providers should raise } \\
\text { their standard of services }\end{array}$ \\
\hline 38. & $\begin{array}{l}\text { Mensah } \\
\text { et al, } 2010^{40}\end{array}$ & $\begin{array}{l}\text { To match the exploits of the } \\
\text { NHIS to the Millennium develop } \\
\text { goals }\end{array}$ & $\begin{array}{l}\text { Propensity score matching } \\
\text { of observational data }\end{array}$ & $\begin{array}{l}400 \text { NHIS } \\
\text { members and } 1600 \\
\text { non-members }\end{array}$ & $\begin{array}{l}\text { Insurance leads to improvement } \\
\text { in perinatal health indicators for } \\
\text { women. Promotion of NHIS in } \\
\text { rural areas is encouraged }\end{array}$ \\
\hline 39. & $\begin{array}{l}\text { Mills et al, } \\
2012^{75}\end{array}$ & $\begin{array}{l}\text { To examine the role impartiality } \\
\text { in financing and utilization of } \\
\text { healthcare plays in universal } \\
\text { access to health in Ghana, } \\
\text { Tanzania, and South Africa }\end{array}$ & $\begin{array}{l}\text { Analysis of primary and } \\
\text { secondary data }\end{array}$ & $\begin{array}{l}\text { NHIS data from } \\
\text { Ghana, South } \\
\text { Africa, and } \\
\text { Tanzania }\end{array}$ & $\begin{array}{l}\text { Health services benefited the rich } \\
\text { more. Barriers to access to } \\
\text { healthcare must be addressed }\end{array}$ \\
\hline
\end{tabular}

(Continued) 
Table I (Continued).

\begin{tabular}{|c|c|c|c|c|c|}
\hline No. & $\begin{array}{l}\text { Author, } \\
\text { Date }\end{array}$ & Purpose of the Study & Methodology & Sample & $\begin{array}{l}\text { Key Findings and } \\
\text { Recommendations }\end{array}$ \\
\hline 40. & $\begin{array}{l}\text { Nguyen } \\
\text { et al, } 2011^{8}\end{array}$ & $\begin{array}{l}\text { To understand how the NHIS } \\
\text { provides economic security }\end{array}$ & Cross-sectional survey & $11,6 \mid 7$ individuals & $\begin{array}{l}\text { A little above one third of the } \\
\text { population were insured. } \\
\text { Insurances provides financial } \\
\text { safety, most especially the poor. } \\
\text { The uninsured made more health } \\
\text { expenses. Other countries with } \\
\text { similar socio-economic profile to } \\
\text { Ghana should initiative an } \\
\text { insurance scheme. }\end{array}$ \\
\hline 41. & $\begin{array}{l}\text { Nsiah- } \\
\text { Boateng \& } \\
\text { Aikins, } \\
2013^{45}\end{array}$ & $\begin{array}{l}\text { To evaluate the execution of the } \\
\text { NHIS in the Ga district }\end{array}$ & $\begin{array}{l}\text { A combination of desk } \\
\text { review and household based } \\
\text { cross-sectional study }\end{array}$ & $\begin{array}{l}2007-2008 \text { audited } \\
\text { accounts, } 2009 \\
\text { unaudited } \\
\text { accounts, and } 376 \\
\text { household heads }\end{array}$ & $\begin{array}{l}\text { Membership enrolment was } \\
\text { marginally higher than aggregate } \\
\text { community enrolment. A huge } \\
\text { chunk of financing of the district } \\
\text { comes from the central NHIS } \\
\text { level. Payments are usually behind } \\
\text { schedule. A more efficient } \\
\text { payment system should be } \\
\text { implemented }\end{array}$ \\
\hline 42. & $\begin{array}{l}\text { Nsiah- } \\
\text { Boateng } \\
\text { et al, } 2016^{52}\end{array}$ & $\begin{array}{l}\text { To evaluate the financial } \\
\text { performance of the NHIS }\end{array}$ & $\begin{array}{l}\text { Analysis of secondary data } \\
\text { from medical claims } \\
\text { between January, } 2010 \text { to } \\
\text { December, } 2014\end{array}$ & 644,663 claims & $\begin{array}{l}\text { Reimbursement claims were } \\
\text { made to the tune of over } \$ 3 \mathrm{~m} \text {. } \\
\text { Between } 20 \mathrm{II} \text { and } 20 \mathrm{I} 4 \text {, there } \\
\text { was at least } 3 \text { months delay in } \\
\text { paying almost all the financial } \\
\text { request made. A marginal } \\
\text { increment in the proportion of } \\
\text { claims rejected was observed } \\
\text { between } 20 \mathrm{II} \text { to } 2014 \text {. Claims } \\
\text { were rejected mainly because } \\
\text { administrative hitches, fraudulent } \\
\text { activities, and technical } \\
\text { judgments. Reforms are } \\
\text { necessary to ensure financial } \\
\text { sustainability of the scheme }\end{array}$ \\
\hline 43. & $\begin{array}{l}\text { Nsiah- } \\
\text { Boateng } \\
\text { et al, } \\
2017^{127}\end{array}$ & $\begin{array}{l}\text { A study to review how NHIS bills } \\
\text { can be minimized }\end{array}$ & $\begin{array}{l}\text { A cross-sectional } \\
\text { comparative assessment of } \\
\text { data from paper and } \\
\text { electronic based claims }\end{array}$ & 173 claims & $\begin{array}{l}\text { Electronic data saves cost. } \\
\text { Government should implement } \\
\text { the electronic system of making } \\
\text { claims across the entire country }\end{array}$ \\
\hline 44. & $\begin{array}{l}\text { Odame } \\
\text { et al, } 2014^{47}\end{array}$ & $\begin{array}{l}\text { To link the disbursement } \\
\text { incurred by the free maternal } \\
\text { policy of the NHIS to the } \\
\text { financial sustainability of the } \\
\text { scheme }\end{array}$ & $\begin{array}{l}\text { Analysis of secondary data } \\
\text { collected from the financial } \\
\text { reports of hospitals }\end{array}$ & $\begin{array}{l}38,883 \text { financial } \\
\text { claims reports }\end{array}$ & $\begin{array}{l}\text { Costs incurred in funding the free } \\
\text { maternal health policy was almost } \\
5 \text {-times the seed grant provided } \\
\text { by donors. Donors should take } \\
\text { the long-term sustainability of the } \\
\text { project into account whilst giving } \\
\text { start up grants }\end{array}$ \\
\hline
\end{tabular}

(Continued) 
Table I (Continued).

\begin{tabular}{|c|c|c|c|c|c|}
\hline No. & $\begin{array}{l}\text { Author, } \\
\text { Date }\end{array}$ & Purpose of the Study & Methodology & Sample & $\begin{array}{l}\text { Key Findings and } \\
\text { Recommendations }\end{array}$ \\
\hline 45. & $\begin{array}{l}\text { Piersson \& } \\
\text { Gorleku, } \\
2017^{61}\end{array}$ & $\begin{array}{l}\text { To appraise the availability, } \\
\text { accessibility, and affordability of } \\
\text { magnetic resonance imaging } \\
\text { services to patients in Ghana }\end{array}$ & $\begin{array}{l}\text { Descriptive cross-sectional } \\
\text { study }\end{array}$ & $\begin{array}{l}\text { I } 3 \text { MRI suites in } \\
\text { tertiary hospitals, } \\
\text { private hospitals, } \\
\text { and private } \\
\text { diagnostic centers }\end{array}$ & $\begin{array}{l}\text { High proportion of citizens do } \\
\text { not have access to MRI scanner. } \\
\text { Unlike private insurance } \\
\text { subscribers, public insurance } \\
\text { subscribers cannot benefit from } \\
\text { MRI services. Government } \\
\text { should provide more MRIs and } \\
\text { make their services payable via } \\
\text { the NHIS }\end{array}$ \\
\hline 46. & $\begin{array}{l}\text { Sackey \& } \\
\text { Amponsah, } \\
2017^{128}\end{array}$ & $\begin{array}{l}\text { To examine the relationship } \\
\text { between positive attitude } \\
\text { towards capitation and economic } \\
\text { status }\end{array}$ & $\begin{array}{l}\text { Descriptive cross-sectional } \\
\text { survey }\end{array}$ & 1299 participants & $\begin{array}{l}\text { Persons of high economic } \\
\text { standing, knowledge on capitation } \\
\text { and in small households accepted } \\
\text { capitation more readily. } \\
\text { Capitation should be a } \\
\text { complementary system, not a } \\
\text { substitution }\end{array}$ \\
\hline 47. & $\begin{array}{l}\text { Seddoh \& } \\
\text { Akor, } \\
2012^{86}\end{array}$ & $\begin{array}{l}\text { To explore the lessons from } \\
\text { political context of the NHIS } \\
\text { policy formulation process }\end{array}$ & $\begin{array}{l}\text { Participant observation } \\
\text { based on retrospect } \\
\text { recollection of information }\end{array}$ & & $\begin{array}{l}\text { Various stakeholders use all kinds } \\
\text { of means to swing the pendulum } \\
\text { in their favor during the policy } \\
\text { formulation process. A four-way } \\
\text { framework for policy formation } \\
\text { which includes agenda setting, } \\
\text { symbols manipulation, } \\
\text { constituency preservation, and } \\
\text { coalition building }\end{array}$ \\
\hline 48. & $\begin{array}{l}\text { Sekyi \& } \\
\text { Domanban, } \\
2012^{73}\end{array}$ & $\begin{array}{l}\text { To measure the impact NHIS has } \\
\text { on healthcare utilization by out- } \\
\text { patients and healthcare financing }\end{array}$ & $\begin{array}{l}\text { Household based cross- } \\
\text { sectional study }\end{array}$ & 384 individuals & $\begin{array}{l}\text { Insured persons used out-patient- } \\
\text { department services more. } \\
\text { Insured persons significantly } \\
\text { made less out-of-pocket } \\
\text { payments. Conscious efforts } \\
\text { aimed at increasing enrolment is } \\
\text { needed }\end{array}$ \\
\hline 49. & $\begin{array}{l}\text { Sodzi- } \\
\text { Tettey et al, } \\
2012^{43}\end{array}$ & $\begin{array}{l}\text { To analyse the factors impeding } \\
\text { on reimbursement }\end{array}$ & $\begin{array}{l}\text { Combination of analysis of } \\
\text { secondary data, and } \\
\text { primary data (in-depth } \\
\text { interviews, and interview } \\
\text { guides) }\end{array}$ & $\begin{array}{l}40 \text { health facilities } \\
\text { in Kassena } \\
\text { Nankana and } 20 \text { in } \\
\text { Builsa Districts }\end{array}$ & $\begin{array}{l}\text { Processing of payments requests } \\
\text { were done manually. Barriers to } \\
\text { reimbursement are administrative } \\
\text { and human resource in nature. } \\
\text { Not more than I\% of requests } \\
\text { were rejected. A modern } \\
\text { payment processing system } \\
\text { should be implemented }\end{array}$ \\
\hline 50. & $\begin{array}{l}\text { Strupat \& } \\
\text { Klohn, } \\
2018^{71}\end{array}$ & $\begin{array}{l}\text { To investigate the impact of the } \\
\text { NHIS on health-related } \\
\text { outcomes }\end{array}$ & $\begin{array}{l}\text { Secondary analysis of data } \\
\text { from fourth and fifth waves } \\
\text { of the Ghana Living } \\
\text { Standards Survey }\end{array}$ & 23,062 participants & $\begin{array}{l}\text { NHIS reduces out-of-pocket } \\
\text { payments. A further investigation } \\
\text { to determine the association } \\
\text { between the reduction in out-of- } \\
\text { pocket payments and the saving } \\
\text { habits of people }\end{array}$ \\
\hline
\end{tabular}

(Continued) 
Table I (Continued).

\begin{tabular}{|c|c|c|c|c|c|}
\hline No. & $\begin{array}{l}\text { Author, } \\
\text { Date }\end{array}$ & Purpose of the Study & Methodology & Sample & $\begin{array}{l}\text { Key Findings and } \\
\text { Recommendations }\end{array}$ \\
\hline 51. & $\begin{array}{l}\text { Yawson } \\
\text { et al, 2012 } 2^{57}\end{array}$ & $\begin{array}{l}\text { To explore how user health } \\
\text { seeking behavior and health } \\
\text { provider practices affect the } \\
\text { NHIS }\end{array}$ & $\begin{array}{l}\text { A combination of analytical } \\
\text { cross-sectional study, and } \\
\text { analysis of secondary data } \\
\text { from Winneba Municipal } \\
\text { Hospital records }\end{array}$ & $\begin{array}{l}\text { I } 75 \text { uninsured and } \\
\text { I } 70 \text { insured } \\
\text { outpatients }\end{array}$ & $\begin{array}{l}\text { The insured sought health more } \\
\text { regularly than the uninsured. The } \\
\text { insured received better quality of } \\
\text { care than the uninsured }\end{array}$ \\
\hline \multirow[t]{2}{*}{52.} & $\begin{array}{l}\text { Yilma et al, } \\
2012^{129}\end{array}$ & $\begin{array}{l}\text { To investigate whether insurance } \\
\text { has adverse effects on healthcare } \\
\text { utilization }\end{array}$ & $\begin{array}{l}\text { A panel including two } \\
\text { surveys in two years } \\
\text { interval }\end{array}$ & 400 households & $\begin{array}{l}\text { Insurance makes people forgo } \\
\text { preventive measures. Unintended } \\
\text { behavioral consequences of } \\
\text { insurance should be controlled }\end{array}$ \\
\hline & \multicolumn{5}{|c|}{ Mixed-Method Studies } \\
\hline I. & $\begin{array}{l}\text { Andoh- } \\
\text { Adjei et al, } \\
2016^{67}\end{array}$ & $\begin{array}{l}\text { To determine the attitude of } \\
\text { people towards capitation } \\
\text { payment, and its impact on the } \\
\text { use of local health facilities }\end{array}$ & Mixed method study & 344 participants & $\begin{array}{l}\text { There is an overall positive } \\
\text { attitude towards the payment of } \\
\text { capitation and registration on the } \\
\text { NHIS. Quality of care and } \\
\text { proximity are two factors that } \\
\text { influence choice of care provider. } \\
\text { Some negative perceptions do } \\
\text { exist, which need to be addressed } \\
\text { by the insurance agency }\end{array}$ \\
\hline 2. & $\begin{array}{l}\text { Andoh- } \\
\text { Adjei et al, } \\
2018^{65}\end{array}$ & $\begin{array}{l}\text { To explore attitude towards } \\
\text { quality of services under the } \\
\text { capitation payment regime }\end{array}$ & Mixed method study & $\begin{array}{l}\text { NHIS membership } \\
\text { in Ashanti, Volta, } \\
\text { and Central } \\
\text { regions }\end{array}$ & $\begin{array}{l}\text { There was a positive perception, } \\
\text { of quality of care. Occupation, } \\
\text { region and length of NHIS } \\
\text { membership are predictors of } \\
\text { positive perception of quality of } \\
\text { care. In terms of region specific } \\
\text { analysis, Voltarians ranked quality } \\
\text { of care better than the Ashanti's. } \\
\text { Authorities should take measures } \\
\text { to improve upon perception of } \\
\text { the NHIS }\end{array}$ \\
\hline 3. & $\begin{array}{l}\text { Agyepong \& } \\
\text { Nagai, } \\
2011^{84}\end{array}$ & $\begin{array}{l}\text { To discover the disparities in the } \\
\text { performance of the NHIS }\end{array}$ & $\begin{array}{l}\text { Mixed methods including } \\
\text { analysis of secondary and } \\
\text { primary data }\end{array}$ & $\begin{array}{l}67 \text { FGD members } \\
\text { and } 300 \text { survey } \\
\text { participants }\end{array}$ & $\begin{array}{l}\text { Providers did not follow the } \\
\text { regulations on exemptions to the } \\
\text { letter. } \\
\text { Clients who knew they were } \\
\text { eligible for exemption did not } \\
\text { demand their rights out of fear. } \\
\text { Policy-makers should collaborate } \\
\text { with frontline workers to address } \\
\text { their concerns }\end{array}$ \\
\hline 4. & $\begin{array}{l}\text { Agyepong } \\
\text { et al, } 2016^{48}\end{array}$ & $\begin{array}{l}\text { To investigate the challenges to } \\
\text { establishing insurance in Ghana }\end{array}$ & $\begin{array}{l}\text { A combination of analysis of } \\
\text { primary (in-depth } \\
\text { interviews, and focus group } \\
\text { discussion) and secondary } \\
\text { data }\end{array}$ & $\begin{array}{l}35 \text { in-depth } \\
\text { interviews, and } 12 \\
\text { FGD }\end{array}$ & $\begin{array}{l}\text { Re-subscription is a major } \\
\text { barrier. Content of insurance } \\
\text { package, and service related } \\
\text { issues influence decision to } \\
\text { subscribe. } \\
\text { Enhanced strategies are needed } \\
\text { to reach universal health } \\
\text { coverage }\end{array}$ \\
\hline
\end{tabular}

(Continued) 
Table I (Continued).

\begin{tabular}{|c|c|c|c|c|c|}
\hline No. & $\begin{array}{l}\text { Author, } \\
\text { Date }\end{array}$ & Purpose of the Study & Methodology & Sample & $\begin{array}{l}\text { Key Findings and } \\
\text { Recommendations }\end{array}$ \\
\hline 5. & $\begin{array}{l}\text { Aryeetey } \\
\text { et al, } 2016^{72}\end{array}$ & $\begin{array}{l}\text { To examine the whether the } \\
\text { NHIS provides financial security } \\
\text { to the vulnerable }\end{array}$ & Mixed methods study & 13,857 & $\begin{array}{l}\text { Membership insulates households } \\
\text { against poverty and health } \\
\text { inflicted financial stress. } \\
\text { Enrolment should be expanded to } \\
\text { the poor }\end{array}$ \\
\hline 6. & $\begin{array}{l}\text { Dalinjong \& } \\
\text { Laar, 2012 } 2^{58}\end{array}$ & $\begin{array}{l}\text { To determine the relative } \\
\text { treatments healthcare workers } \\
\text { give out to the insured and } \\
\text { uninsured }\end{array}$ & Mixed methods study & $\begin{array}{l}200 \text { survey } \\
\text { participants, } 15 \text { ln- } \\
\text { depth interviews } \\
\text { and 8FGD }\end{array}$ & $\begin{array}{l}\text { NHIS members have increased } \\
\text { access to healthcare. Both } \\
\text { insured and uninsured are } \\
\text { satisfied with the quality of } \\
\text { treatment they receive. Insured } \\
\text { believe attitude of workers } \\
\text { towards them is cold due to the } \\
\text { cash of the uninsured. Rates of } \\
\text { payment of claims are a concern. } \\
\text { Challenges should be addressed } \\
\text { to ensure customer satisfaction }\end{array}$ \\
\hline 7. & $\begin{array}{l}\text { Dalinjong } \\
\text { et al, } 2018^{39}\end{array}$ & $\begin{array}{l}\text { To assess the opinion on pricing, } \\
\text { and prevalence of out-patient- } \\
\text { payments by antenatal women }\end{array}$ & $\begin{array}{l}\text { Primary data collected using } \\
\text { mixed methods approach }\end{array}$ & $\begin{array}{l}406 \text { women for } \\
\text { quantitative } \\
\text { component, and } \\
38 \text { participants for } \\
\text { qualitative } \\
\text { component }\end{array}$ & $\begin{array}{l}\text { Scheme only partially covers cost. } \\
\text { GH } \not 17.50(\$ 8.60) \text { was the } \\
\text { average out-of-pocket payment } \\
\text { made. Measures should be put in } \\
\text { place to reduce or eliminate all } \\
\text { costs related to maternal services }\end{array}$ \\
\hline 8. & $\begin{array}{l}\text { Hampshire } \\
\text { et al, 20I I }{ }^{28}\end{array}$ & $\begin{array}{l}\text { To investigate healthcare } \\
\text { utilization by children }\end{array}$ & Mixed methods study & $\begin{array}{l}\text { I005 quantitative } \\
\text { and I } 3 \mid \text { qualitative } \\
\text { respondents }\end{array}$ & $\begin{array}{l}\text { There are socio-cultural and } \\
\text { economic barriers to access to } \\
\text { health. } \\
\text { Insurance presents an } \\
\text { opportunity to resolve these } \\
\text { challenges. Enrolment should be } \\
\text { increased strategically }\end{array}$ \\
\hline
\end{tabular}

and should be continued. The more vulnerable groups should be exempted from paying the NHIS premium. This will ensure that coverage is extended to the poor. ${ }^{40,41}$

\section{Financing}

Both health revenue and expenditure increased because of NHIS. ${ }^{42}$ Enrolment in the scheme increased continually, though there was a high rate of non-renewal putting the scheme under high financial stress. This section describes the sources of funding, subscription, and renewal. In a study to enlist the challenges that the implementation of the NHIS has encountered, Sodzi-Tettey et $\mathrm{al}^{43}$ discovered that the scheme was threatened by organizational, financial, and administrative problems. The authors recommended, amongst other things, the adoption of a more modern payment system to salvage the future of the scheme.

\section{Funding}

The scheme is predominantly funded through taxes, specifically $2.5 \%$ of the $17.5 \%$ VAT, $2.5 \%$ of the $17.5 \%$ SSNIT from formal sector employees, dividends of investments made by the NHIA Council, donations, and premium payments. ${ }^{44-46}$ Addae-Korankye ${ }^{38}$ revealed that there is inadequate funding for the NHIS. Costs incurred in funding the free maternal health policy were almost 5times the seed grant provided by donors. ${ }^{47}$

\section{Enrolment and Resubscription}

Enrolment and resubscription is a major barrier under the scheme. ${ }^{48}$ Enrolment in the scheme increased in multiple folds since its inception. ${ }^{44}$ Many studies ${ }^{8,32,34-36}$ reported varying proportions of enrolment. Boateng and AwunyorVitor $^{35}$ discovered that out of the $61.1 \%$ of their 


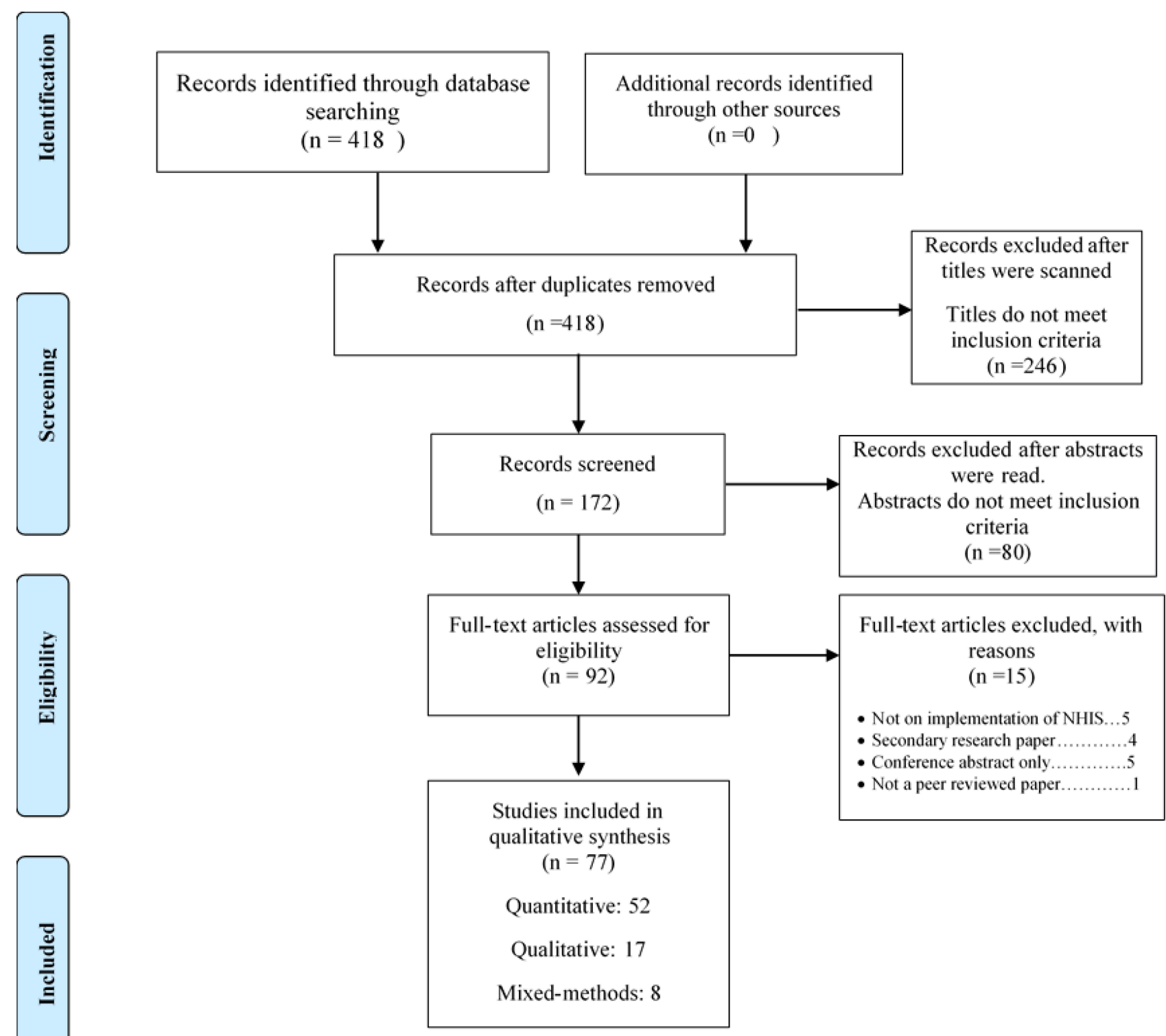

Figure I Search, appraisal, and inclusion of studies.

Note: Reviews and Meta-Analyses: The PRISMA Statement. PLoS Med 6(6): el000097. doi:10.137I/journal.pmedI 00009.

respondents who were enrolled in the NHIS, $23.9 \%$ had not renewed their insurance after enrolment. ${ }^{35}$ High rate of non-renewal put the scheme under financial stress. ${ }^{34}$ Factors that influenced resubscription included age, economic status, usefulness, accessibility, affordability, and perception of the quality of service provided. ${ }^{36,41}$ Also, the probability of resubscription was proportional to having used the services in the previous year. ${ }^{49}$ Adei et $\mathrm{al}^{34}$ advised that the government should consider implementing the one-time premium payment.

\section{Reimbursement of Providers}

Default in paying service providers for the services provided for clients under the scheme negatively affected the implementation of the NHIS. ${ }^{42,50,51}$ Between 2011 and 2014, there was at least 4 months delay in paying almost all the financial claims made. ${ }^{52}$ This was as a result of poor funding, manual processing of claims, and mismanagement of scheme funds. ${ }^{43,53}$ To tackle the financial challenges surrounding the scheme, researchers ${ }^{45,53}$ advocated that proper financing mechanisms should be implemented. 


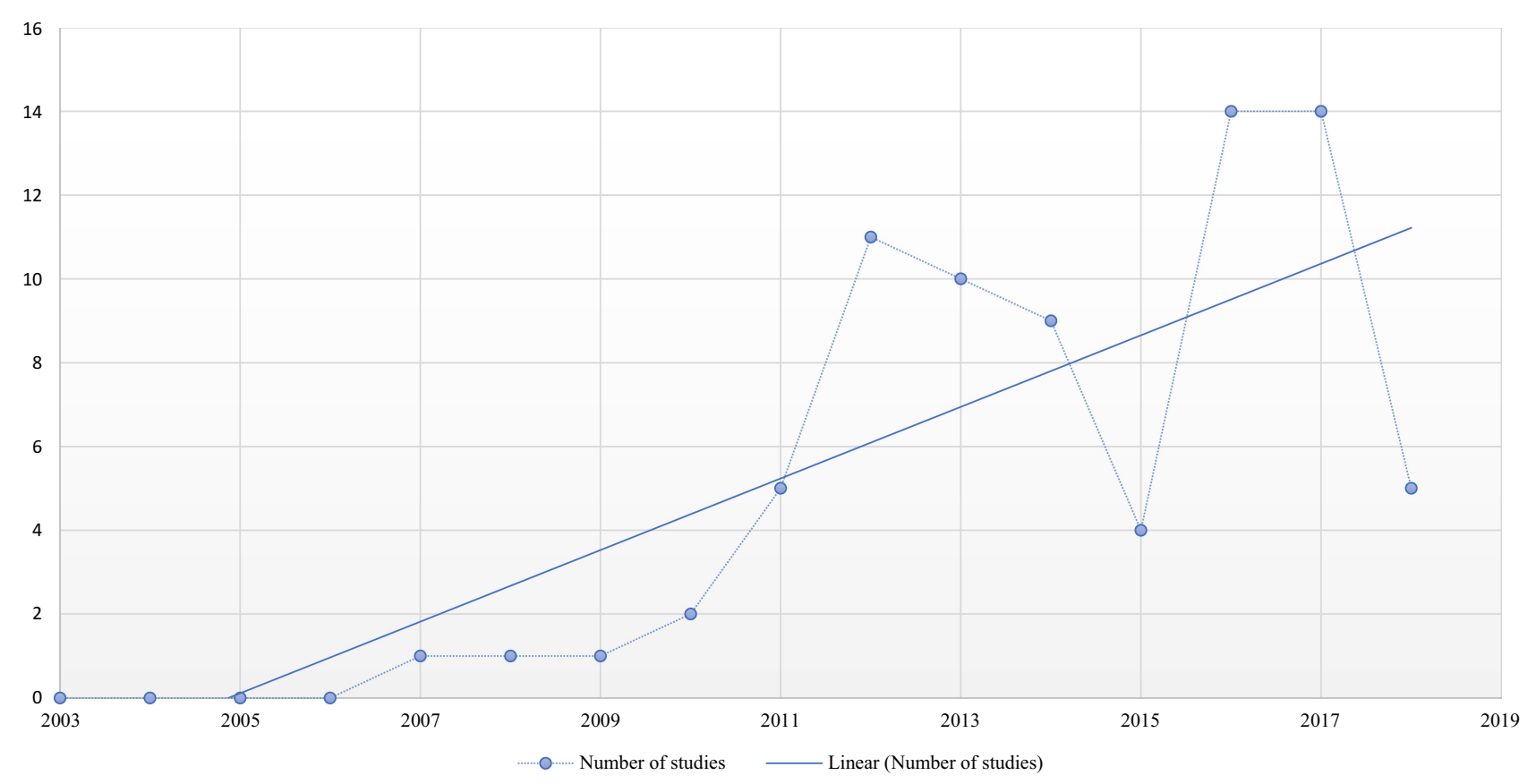

Figure 2 Yearly distribution of studies included in the review.

NHIS Active Membership in Ghana (2005-2017)

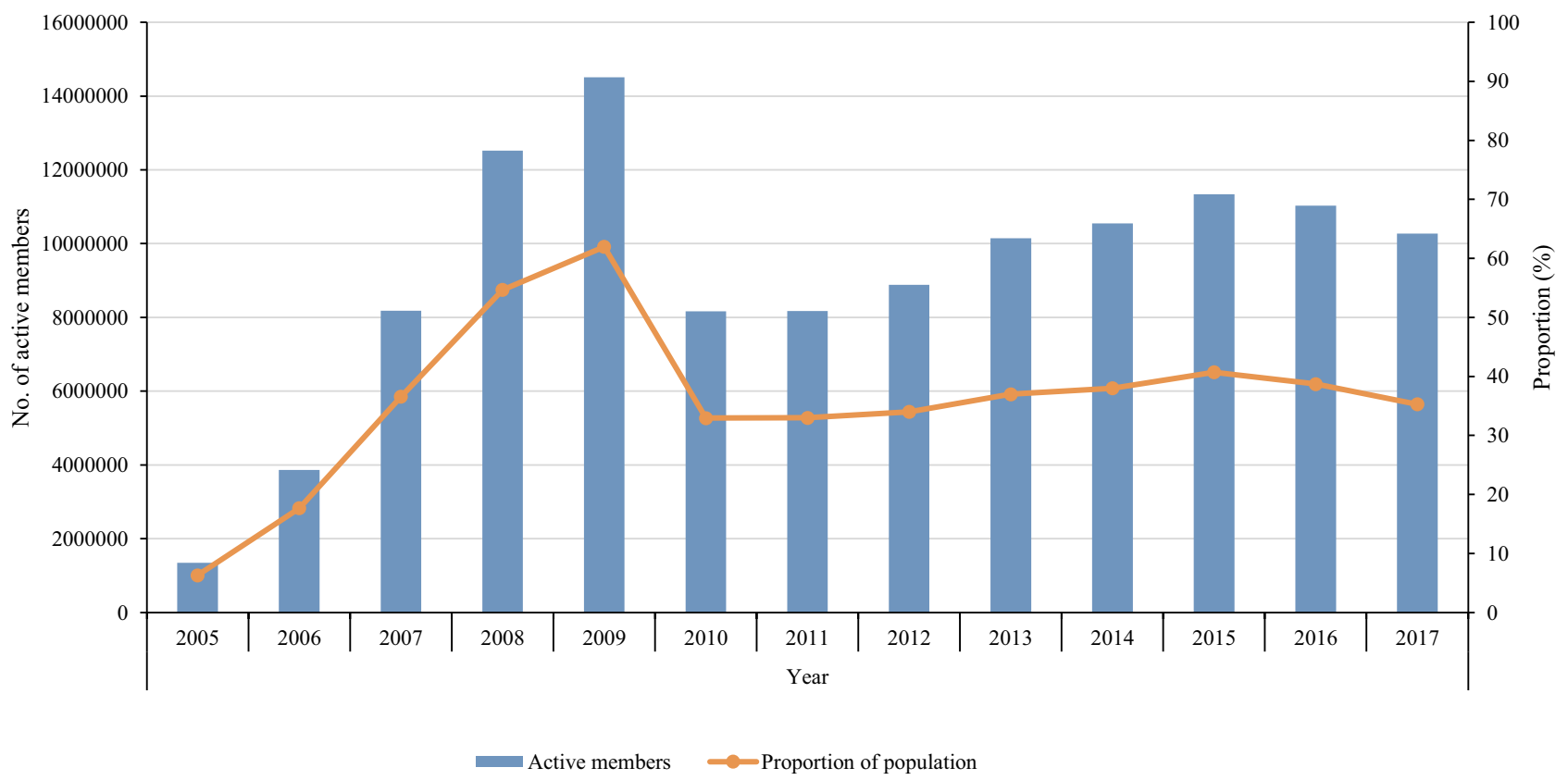

Figure 3 NHIS Active Membership from 2005 to 2017 (Source: National Health Insurance Authority ${ }^{118}{ }^{119}$; Nsiah-Boateng \& Aikins ${ }^{120} 2018$ ).

Service Delivery

Quality, Attitudes of Providers, and User Satisfaction

Primary healthcare centers lacked adequate resources to discharge their services, thereby providing poor quality of preventative services under the scheme..$^{50,54}$ User satisfaction with the services provided under the NHIS was below average. Only one-third of the facilities delivered efficient services, public facilities delivered more efficient services 
than private and mission facilities. ${ }^{55,56}$ Those insured under the scheme were more dissatisfied with service provided than the uninsured, ${ }^{10,11}$ in contrast to the findings of Yawson et $\mathrm{al}^{57}$ that the insured received a better quality of care than the uninsured. Dalinjong and Laar ${ }^{58}$ also reported that both insured and uninsured were satisfied with the quality of treatment they received.

The poor mostly used community health centers, whilst the rich and the uninsured mostly patronized public hospitals and private centers, respectively. ${ }^{31}$ Wealthy men perceived the services of the scheme as inferior to other mmodes, however, wealthy women did not perceive the services of the scheme to be inferior to other alternatives. ${ }^{59}$ Unlike community health compounds, dominant proportions of women who sought ANC services at hospitals and health centers delivered their babies at these facilities. ${ }^{29}$ Rural facilities had higher chances of being more competent than urban ones. ${ }^{55}$ Asundep et al ${ }^{60}$ found that $20 \%$ of women accessing care through the scheme experienced adverse health outcomes. ${ }^{60} \mathrm{~A}$ high proportion of citizens did not have access to an MRI scanner. ${ }^{61}$ Also, long waiting time in the hospitals was a disincentive for people to subscribe to the scheme. ${ }^{36}$ Quality improvement measures should be instituted to improve the quality of services provided to the clients, especially in the private healthcare facilities. $^{62,63}$

The access and financial protection provided by the scheme have improved health-seeking behaviors and reduced risky health behaviors such as self-medication among Ghanaians. ${ }^{64}$ Though some studies ${ }^{42,65}$ reported a positive attitude of providers towards service delivery, others ${ }^{10}$ reported poor attitudes of providers. Use of traditional medicine was high amongst both insured and uninsured but had no association with insurance status. ${ }^{66}$ Quality of care and proximity were two factors that influenced the choice of care provider. ${ }^{67}$

\section{Outcomes}

Those insured under the scheme believed that providers had poorer attitudes towards them than those who are not insured under the scheme. ${ }^{58}$ There was no statistically significant difference in the occurrence of low birth weight in before and after the implementation of the NHIS. ${ }^{68}$ However, the proportion of infant mortality recorded before the implementation of the scheme was halved during the insurance period; likewise, more maternal deaths were recorded in the previous system as compared to the NHIS regime. ${ }^{69}$ Also, a higher number of cesarean sections were conducted in the NHIS period than before. ${ }^{69}$ Lambon-Quayefio and Owoo $^{70}$ observed that insurance significantly reduced neonatal death. Mensah et $\mathrm{al}^{40}$ also recorded that insurance leads to improvements in perinatal health indicators for women. Nguyen et al, ${ }^{8}$ Strupat and Klohn, ${ }^{71}$ and Aryeetey et $\mathrm{l}^{72}$ also found that the uninsured had more health expenses than the insured. Therefore, the insured sought to use health services more than the uninsured. ${ }^{57,58,73}$

\section{Failures/Challenges}

After 10 years of implementation (2003-2013) less than $40 \%$ of the population of Ghana had subscribed to the NHIS. National coverage or UHC is far from reach at this pace. National Health Insurance as portrayed by the government and the policy document is to protect the population against the negative consequences of the cost of healthcare. Though the NHIS was envisaged to be more preventive than curative it has lost its preventive nature and is currently more curative.$^{24}$ The scheme is not as pro-poor as it has been envisaged. ${ }^{74}$ Mills et al stated that the policy favored the rich rather than the poor it was intended to, creating much more burden on the poor. ${ }^{75}$ Because, the rich and the poor pay the same amount to subscribe to the scheme but the rich access private fee-forservice healthcarewhen the NHI accredited facilities run out of medicines and other healthcare supplies.

Systemic corruption in sub-Saharan African institutions is a threat to the sustainability of the financial model in Ghana. Healthcare institutions issue false claims for reimbursement; some healthcare users admitted conniving with healthcare providers to defraud the scheme. ${ }^{25,76}$ Systems need to be put in place to keep the policy relevant to its purpose. As the health system develops and the health needs of the population change, a policy review will be necessary to make it effective.

\section{Governance}

This section covers system design, coalition building, transparency, oversight, and accountability. ${ }^{77}$ The sustainability of the NHIS in Ghana is of grave concern. It seems as though the implementation of the scheme was rushed. ${ }^{78}$ There was more emphasis on the roles of political actors than the technical insight provided by experts in the field of public health insurance policy. ${ }^{78}$ Whilst recognizing the crucial role that the political elite play in the formulation of public policy, Agyepong and Adjei ${ }^{78}$ cautioned that the overarching influence that the political class had on the 
program design and implementation could be a threat to the realization of its goals and objectives .

\section{Financial Management}

There are enough sources of funding for the scheme; corruption, mismanagement, lack of transparency in the funding, claims, and reimbursement issues should be checked by the leadership of the scheme. The government should implement the electronic claims, verification, and reimbursement system across the entire country to curb corruption and default in reimbursement of facilities. ${ }^{46,52}$ There is too much wastage in the NHIS, which should be dealt with by various stakeholders. ${ }^{55}$ Measures should be put in place to reach $100 \%$ subscription and resubscription status to raise more funds for the scheme. ${ }^{49}$ Also, the rich should be made to pay more to increase the funds for the scheme. ${ }^{38}$

\section{System Design and Oversight}

Political machinations and poor monitoring and evaluation hinder the smooth running of the scheme. ${ }^{54}$ Other challenges to the scheme are in the form of inadequate workforce and weak institutional arrangements and transparency. ${ }^{43,44,79}$ Administration at both central and local levels affect the decision of people to subscribe to the scheme and continue their subscription. ${ }^{80}$ The NHIS needs to be reviewed to ensure good leadership and governance, transparent and accountable institutional arrangement, and effectiveness and sustainability of the scheme. ${ }^{79,81,82}$

\section{Community Participation}

Lack of community participation is a common phenomenon in SSA. Many studies $23,50,51,59,74,83$ reported lack of community participation in the NHIS policy formulation and implementation. The policy resulted from a political campaign and the stakeholders knew only the intended political messages. They were not further educated on the consequences of registering or not as well as the details of the technical language that was contained in the policy document. Many people cannot demand services because they either do not understand or are afraid to ask questions about the package. ${ }^{84}$ People need to be empowered to demand services they are due. ${ }^{84}$ Researchers recommended the need for stakeholder consultation in improving and sustaining the scheme. ${ }^{50,51,59,74,83}$

\section{Competing Interest}

Politicians attempted to make political gains out of the finances of the scheme at the expense of the development of the scheme. ${ }^{85}$ Because it was a political campaign promise, stakeholder consultation and input produced friction, as the politicians pushed to achieve their campaign promises, whether realistic or not. It is necessary for the politicians to know their boundaries and delegate the technocrats to superintend policies of such a magnitude. ${ }^{78}$ Other stakeholders of the scheme also tried to swing the policy in their favor using all means. ${ }^{86}$ Institutional arrangements among all stakeholder groups should be determined with terms of reference that will enhance the policy implementation. There is need for all stakeholders to clearly understand the content of the policy to avoid ambiguity and role conflicts. ${ }^{4,85}$

\section{Discussion}

From the results, Ghana has contributed much in efforts and funding to make the NHIS work but has struggled with issues of coverage, funding, stakeholder participation, and governance. Corruption and political interference are also seen as major threats to the sustenance of the scheme.

The proportion of the population enrolled in the NHIS from its inception has been less than $41 \%$, apart from 2008 and 2009 where the scheme unexpectedly recorded $54.66 \%$ and $61.97 \%$, respectively. This was attributed to the inability of the Scheme management to exclude the members who had not renewed their membership since the inception of the scheme. In 2008, the NHIS was at the center stage of the national election campaign, and politicians were seen enrolling people as part of the election campaign. This may also account for the higher figures in 2009 as elections were held in December 2008. Other reports cited indicated that the scheme had difficulty in reimbursing service providers coupled with administrative challenges, resulting in dissatisfaction of members who intentionally did not renew their membership. This resulted in a sharp decline in membership to $32.95 \%$ in 2010. The scheme recorded a slow increase in membership from 2010 to 2015; then took another downward stroke due to apathy among subscribers as a result of the delay in reimbursement of health service providers and charging of unapproved fees. ${ }^{87,88}$

Unlike Ghana, South Africa will not have issues with subscription, premium payment, and waivers for certain groups of people. The NHI bill provides for free healthcare for all South Africans. ${ }^{89}$ This allows healthcare to be completely accessible to all the population. Many stakeholders in South Africa are seeking clarification on the source of funding, modes of facility reimbursement, and 
the ability of the system to resist corruption..$^{90-96}$ These critical questions need to be addressed to avoid system collapse. Various forms of inclusive sources of funding should be prioritized as well as efficient use of resources within the NHI in South Africa. ${ }^{91,96}$ The gross inequity in South Africa may be deepened if the system is not designed to address resource allocation and funding mechanisms.

The financial stress that the NHIS is subjected to is partly because $65 \%$ of the active members are exempted from paying premiums. This group is made up of mostly pregnant women, children under 18 years of age, the aged (70 years and above), and indigents. Though the exemption has led to increased access to quality healthcare by the exempted groupings, the burden of the care provided stresses the NHIS financially. Enough funding is made available from the various sources of funding, for example, the highest claims paid to health facilities was $81.1 \%$ of total income by the scheme. Poor governance and corruption as a result of poor stakeholder participation and political influence were cited as the major challenges threatening the financial sustainability of the scheme. ${ }^{43,4547,52,53}$

Even though the private sector caters for the health needs of $16 \%$ of the South Africans as opposed to the $84 \%$ that the public sector serves, private sector consumers account for $52 \%$ of the nation's health sector budget, whilst the public sector accounts for a paltry $48 \% .{ }^{97}$ The gross inequality created by the huge but less funded public sector and small but heavily funded private healthcare system is alarming and needs a system redesign. The National Health Insurance is a strategic political attempt to bridge the healthcare access and quality gap between the poor and the rich by the African National Congress. ${ }^{98}$ The entire NHI policy was expected to be rolled out in three phases within 14 years from 2012. ${ }^{99}$ After 7 years, stakeholders are concerned about the implementation of the NHI, especially in the areas of quality of the healthcare, corruption, mismanagement of funds, fear of overcrowding of private hospitals, poor attitudes of healthcare workers, and reimbursement mechanism. ${ }^{90,98,100-103}$

As seen in Ghana, both private and public healthcare sectors in South Africa have come under intense criticism regarding the quality of healthcare provided. ${ }^{104}$ Many believe that the current public health system needs a system clean-up and reorientation because of gross mismanagement, corruption, and poor quality of services provided. ${ }^{98}$ Though there is a general positive perception about the quality of healthcare provided in the private sector, 104 findings from a study conducted by the University of Cape Town revealed high malpractice within the private sector in South Africa. ${ }^{105}$ Though the $\mathrm{NHI} / \mathrm{UHC}$ policies increase access to healthcare, it is necessary to look at the quality of care provided within the UHC, as poor quality of care tends to be costly in the long-term. ${ }^{106-108}$

In South Africa, the majority of the stakeholders believe that the policy-shift is inevitable. The fear, however, is the clarity in the roles of all stakeholders. ${ }^{109}$ General practitioners and specialists who practice or moonlight in the private sector, the private medical schemes, and the private hospital groups feel threatened and targeted by the policy. Stakeholders are calling for the NHI bill to clarify issues regarding the role of existing medical schemes, the NHI referral pathway, the benefit packages, and sources of funding. ${ }^{93,96}$

Policymakers should endeavor to involve frontline workers in addressing the concerns of the scheme. ${ }^{84}$ Communities should be encouraged through public education to expand the coverage of the scheme. ${ }^{35}$ Public awareness programs should be instituted to improve user knowledge and confidence in the scheme. ${ }^{110}$ Encouraging stakeholder participation in decision-making is widely recommended. ${ }^{91,109,111-113}$ Barker and Klopper ${ }^{112}$ reported that the community studied resisted taking power and decision-making roles in planning and delivering care Participation in decision-making is the constitutional right of the communities in South Africa and must be respected by engaging them in critical decisions that affect their livelihood. ${ }^{114}$ Lastly, communities need to be empowered to demand accountability.

Many bright institutions have fallen because of poor and ineffective leadership in sub-Saharan Africa. Political influence in institutions that are expected to be autonomous is evident across the continent, especially when the government has a role in the appointment of the leadership and funding the institution. Corruption among healthcare leadership is a cancer that eats deep to the core of the healthcare sector in South Africa. ${ }^{95}$ Corruption is capable of making healthcare institutions resource-poor, ineffective, and produce poor quality health outcomes. Therefore, the South African healthcare system needs to be redesigned to curb corruption, especially when the NHI bill seeks to consolidate healthcare funds to be managed by boards that are accountable to a political authority, the Minister of Health. ${ }^{95,115}$ 
Many stakeholders also believe that the policy confers too much power on the Minister of Health to appoint and superintend committees; an ineffective or corrupt Minister of Health could destroy the wellintended healthcare system and funding mechanism. Opposition parties in parliament also believe that the NHI is a mechanism for the ruling party and its appointees to steal taxpayers' money to enrich themselves. The Minister of Health, Dr Zweli Mkhize, however, said that the president recognizes the threat corruption poses to the insurance and has inaugurated health sector anticorruption forum to check corruption within the NHI system..$^{94}$ Good leadership and governance are essential to the implementation of NHI. Despite the imminent need for the implementation of the NHI in South Africa, the systems need to be redesigned to provide quality and resist corruption and mismanagement. ${ }^{98}$

\section{Conclusion}

The implementation of the NHIS in Ghana has provided access to healthcare for the underprivileged despite the numerous challenges. The scheme has successfully expanded care and protected the poor against the negative consequences of healthcare cost for a decade and a half. Nguyen et $\mathrm{al}^{8}$ recommended that other countries learn from the NHIS policy in Ghana, and implement a similar policy towards UHC. South Africa has a more robust economy and double the population of Ghana but has historical and sociocultural similarities with Ghana. Despite the huge capital ingestion into the healthcare sector, South African health indicators have not improved compared to countries that have similar or lesser capital inputs. This has been mainly attributed to the publicprivate, rich-poor, and rural-urban inequalities in healthcare delivery. ${ }^{116,117}$ The NHI policy is widely accepted as the means of eliminating inequalities in the healthcare system. Therefore, the success of NHI is imperative. Learning from a system that worked within the same region and building systems that overcome the mistakes, challenges, and roadblocks in the already implemented systems are essential.

\section{Acknowledgment}

We will like to acknowledge Professors Janet Gross and Laetitia Rispel for their support during the review process. We will also like to acknowledge Joanna Briggs Institute certified reviewers Dr Emmanuel Frimpong and Chenai Mlandu for their assistance in critical appraisal and inclusion of studies. Many thanks to the Centre for Health Professions Education, NorthWest University for their support during the manuscrip review phase.

\section{Author Contributions}

All authors made substantial contributions to the conception and design, acquisition of data, or analysis and interpretation of data; took part in drafting the article or revising it critically for important intellectual content; gave final approval of the version to be published; and agree to be accountable for all aspects of the work.

\section{Funding}

There was no external funding for this study.

\section{Disclosure}

There were no conflicts of interest regarding this study.

\section{References}

1. Obermann K, Jowett M, Kwon S. The role of national health insurance for achieving UHC in the Philippines: a mixed methods analysis. Glob Health Action. 2018;11(1):1483638. doi:10.1080/ 16549716.2018.1483638

2. Fusheini A, Eyles J. Achieving universal health coverage in South Africa through a district health system approach: conflicting ideologies of health care provision. BMC Health Serv Res. 2016;16:558.

3. Cuadrado C, Crispi F, Libuy M, Marchildon G, Cid C. National Health Insurance: a conceptual framework from conflicting typologies. Health Policy (New York). 2019;123(7):621-629. doi:10.1016/ j.healthpol.2019.05.013

4. Carapinha JL, Ross-degnan D, Tamer A, Wagner AK. Health insurance systems in five sub-Saharan African countries: medicine benefits and data for decision making. Health Policy (New York). 2011;99:193-202. doi:10.1016/j.healthpol.2010.11.009

5. Demissie B, Gutema Negeri K. Effect of community-based health insurance on utilization of outpatient health care services in Southern Ethiopia: a comparative cross-sectional study. Risk Manag Healthc Policy. 2020;13:141-153. doi:10.2147/RMHP.S215836

6. Basaza R. What are the emerging features of community health insurance schemes in east Africa? Risk Manag Healthc Policy. 2009;2:47. doi:10.2147/RMHP.S4347

7. Wang H, Otoo N, Dsane-Selby L. Ghana National Health Insurance Scheme: ImprovingFinancial Sustainability Based on Expenditure Review. Washington: World Bank Group; 2017.

8. Nguyen HTH, Rajkotia Y, Wang $\mathrm{H}$. The financial protection effect of Ghana National Health Insurance Scheme: evidence from a study in two rural districts. Int $J$ Equity Health. 2011;10:1-12. doi:10.1186/1475-9276-10-4

9. Badu E, Agyei-Baffour P, Ofori Acheampong I, Preprah Opoku M, Addai-Donkor K. Households sociodemographic profile as predictors of health insurance uptake and service utilization: a cross-sectional study in a municipality of Ghana. Adv Public Health. 2018;2018:1-13. doi:10.1155/2018/7814206

10. Jehu-Appiah C, Aryeetey G, Agyepong I, Spaan E, Baltussen R. Household perceptions and their implications for enrolment in the National Health Insurance Scheme in Ghana. Health Policy Plan. 2012;27:222-233. doi:10.1093/heapol/czr032 
11. Duku SKO, Nketiah-amponsah E, Janssens W, et al. Perceptions of healthcare quality in Ghana: does health insurance status matter? PLoS One. 2018;13:1-18. doi:10.1371/journal.pone.0190911

12. Sithole HL. An overview of the National Health Insurance and its possible impact on eye healthcare services in South Africa. African Vis Eye Health. 2015;74:1-6.

13. Booysen F, Hongoro C. Perceptions of and support for national health insurance in South Africa's public and private healthcare sectors. Pan Afr Med J. 2018;8688:1-9.

14. Levac D, Colquhoun H, O'Brien KK. Scoping studies: advancing the methodology. Implement Sci. 2010;5:69. doi:10.1186/17485908-5-69

15. Christmals CD, Armstrong SJ. The essence, opportunities and threats to advanced practice nursing in Sub-Saharan Africa: a scoping review. Heliyon. 2019;5(10):e02531. doi:10.1016/j.heliyon.2019.e02531

16. Mendeley. Free Reference Manager \& Citation Generator Mendeley. Elsevier; 2018:1.

17. Christmals CD, Gross J, Aziato L, Armstrong SJ. The state of nursing research in Ghana: an integrative literature review. SAGE Open Nurs. 2018;4:237796081878382. doi:10.1177/2377960818 783820

18. Sandelowski M, Voils CI, Leeman J, Crandell JL. Mapping the mixed methods - mixed research synthesis Terrain. J Mix Methods Res. 2012;6:317-331. doi:10.1177/1558689811427913

19. Hsieh HF, Shannon SE. Three approaches to qualitative content analysis. Qual Health Res. 2005;15:1277-1288. doi:10.1177/ 1049732305276687

20. Tricco AC, Lillie E, Zarin W, et al. PRISMA extension for scoping reviews (PRISMA-ScR): checklist and explanation. Ann Intern Med. 2018;169:467. doi:10.7326/M18-0850

21. Abiiro GA, McIntyre D. Universal financial protection through National Health Insurance: a stakeholder analysis of the proposed one-time premium payment policy in Ghana. Health Policy Plan. 2013;28:263-278. doi:10.1093/heapol/czs059

22. Aryeetey GC, Jehu-Appiah C, Kotoh AM, et al. Community concepts of poverty: an application to premium exemptions in Ghana's National Health Insurance Scheme. Global Health. 2013;9:1-11. doi:10.1186/1744-8603-9-12

23. Agyei-Baffour P, Oppong R, Boateng D. Knowledge, perceptions and expectations of capitation payment system in a health insurance setting: a repeated survey of clients and health providers in Kumasi, Ghana. BMC Public Health. 2013;13:1-9. doi:10.1186/ 1471-2458-13-1220

24. Ashigbie PG, Azameti D, Wirtz VJ. Challenges of medicines management in the public and private sector under Ghana's National Health Insurance Scheme - a qualitative study. $J$ Pharm Policy Pract. 2016;9:1-10. doi:10.1186/s40545-0160055-9

25. Barimah KB, Mensah J. Ghana's national health insurance scheme: insights from members, administrators and health care providers. J Health Care Poor Underserved. 2013;24:1378-1390. doi:10.1353/hpu.2013.0144

26. Dalaba MA, Aborigo R, Akweongo P, et al. Does the National Health Insurance Scheme in Ghana reduce household cost of treating malaria in the Kassena-Nankana districts? Glob Health Action. 2014;7:7. doi:10.3402/gha.v7.23848

27. Fosu R, Opoku-asante K, Adu-Gyamfi K. Influence of community financing health insurance schemes on in-patient care in Ghana: the case of Nkoranza scheme. Dev Country Stud. 2014;4:53-64.

28. Hampshire KR, Porter G, Asiedu S, Tanle A, Abane A. Social science \& medicine out of the reach of children? Young people' health-seeking practices and agency in Africa's newly-emerging therapeutic landscapes. Soc Sci Med. 2011;73:702-710. doi:10.1016/j.socscimed.2011.06.035
29. Frimpong JA, Helleringer S, Awoonor-Williams JK, Aguilar T, Phillips JF, Yeji F. The complex association of health insurance and maternal health services in the context of a premium exemption for pregnant women: A case study in Northern Ghana. Health Policy Plan. 2014;29:1043-1053. doi:10.1093/heapol/czt086

30. Asundep NN, Carson AP, Archer C, et al. Determinants of access to antenatal care and birth outcomes in Kumasi, Ghana. $J$ Epidemiol Glob Health. 2013;3(4):279-288.

31. Dalinjong PA, Welaga P, Akazili J, et al. The association between health insurance status and utilization of health services in rural Northern Ghana: evidence from the introduction of the National Health Insurance Scheme. J Health Popul Nutr. 2017;36:1-11.

32. Fenny AP, Enemark U, Asante FA, Hansen KS. Patient satisfaction with primary health care - a comparison between the insured and non-insured under the national health insurance policy in Ghana. Glob J Health Sci. 2014;6:9-21. doi:10.5539/gjhs.v6n4p9

33. Osei Asibey B, Agyemang S. Analysing the influence of health insurance status on peoples' health seeking behaviour in Rural Ghana. J Trop Med. 2017;2017:7. doi:10.1155/2017/8486451

34. Adei D, Kwadwo VO, Diko SK. An assessment of the Kwabre district mutual health insurance scheme in Ghana. Curr Res J Soc Sci. 2012;4:372-382.

35. Boateng D, Awunyor-Vitor D. Health insurance in Ghana: evaluation of policy holders' perceptions and factors influencing policy renewal in the Volta region. Int $J$ Equity Health. 2013;12:1. doi:10.1186/1475-9276-12-50

36. Boateng S, Amoako P, Poku AA, Baabereyir A, Gyasi RM. Migrant female head porters , enrolment in and utilisation and renewal of the National Health Insurance Scheme in Kumasi, Ghana. J Public Health (Bangkok). 2017;25:625-634. doi:10. 1007/s10389-017-0832-1

37. Akazili J, Ataguba JEO, Kanmiki EW, et al. Assessing the impoverishment effects of out-of-pocket healthcare payments prior to the uptake of the national health insurance scheme in Ghana. BMC Int Health Hum Rights. 2017;17:1-9. doi:10.1186/s12914-017-0121-7

38. Addae-Korankye A. Challenges of financing health care in Ghana: the case of National Health Insurance Scheme (NHIS). Int J Asian Soc Sci. 2013;3:511-522.

39. Dalinjong PA, Wang AY, Homer CSE. Has the free maternal health policy eliminated out of pocket payments for maternal health services? Views of women, health providers and insurance managers in Northern Ghana. PLoS One. 2018;13:1-20. doi:10.1371/journal.pone.0184830

40. Mensah J, Oppong JR, Schmidt CM. Ghana's National Health Insurance Scheme in the context of the health MDGs: an empirical evaluation using propensity score matching. Health Econ. 2010;19:95-106. doi:10.1002/hec.1633

41. Jehu-Appiah C, Aryeetey G, Spaan E, et al. Equity aspects of the National Health Insurance Scheme in Ghana: who is enrolling, who is not and why? Soc Sci Med. 2011;72:157-165. doi:10.1016/j.socscimed.2010.10.025

42. Aryeetey GC, Nonvignon J, Amissah C, Buckle G, Aikins M. Migrating from user fees to social health insurance: exploring the prospects and challenges for hospital management. BMC Health Serv Res. 2016;12:1-9.

43. Sodzi-Tettey S, Aikins M, Awoonor-Williams J, Agyepong IA Challenges in provider payment under the Ghana Na- Tional health insurance scheme: a case study of claims. Ghana Med J. 2012;46:189-200.

44. Witter S, Garshong B. Something old or something new? Social health insurance in Ghana. BMC Int Health Hum Rights. 2009;9:1-13. doi:10.1186/1472-698X-9-20

45. Nsiah-boateng E, Aikins M. Performance assessment of ga district mutual health insurance scheme, greater accra region, Ghana. Value Health Reg Issues. 2013;2:300-305. doi:10.1016/j.vhri.20 13.06 .005 
46. Yevutsey SK, Aikins M. Financial viability of district mutual health insurance schemes of lawra and sissala East districts, upper west region, ghana. Ghana Med J. 2010;44:130-137. doi:10.4314/gmj.v44i4.68905

47. Odame EA, Akweongo P, Yankah B, Asenso-boadi F, Agyepong I. Sustainability of recurrent expenditure on public social welfare programmes: expenditure analysis of the free maternal care programme of the Ghana National Health Insurance Scheme. Health Policy Plan. 2014;29:271-279. doi:10.1093/heapol/czt013

48. Agyepong IA, Nana D, Abankwah Y, et al. Policy and implementation challenges and dilemmas of a lower middle income country. Natl Health Insur Scheme. 2016;16:1-14.

49. Duku SKO, Asenso-boadi F, Nketiah-amponsah E, Arhinful DK. Utilization of healthcare services and renewal of health insurance membership: evidence of adverse selection in Ghana. Health Econ Rev. 2016;6:1-12. doi:10.1186/s13561-016-0122-6

50. Awoonor-Williams JK, Tindana P, Dalinjong PA, Nartey H, Akazili J. Does the operations of the National Health Insurance Scheme (NHIS) in Ghana align with the goals of Primary Health Care? Perspectives of key stakeholders in northern Ghana. BMC Int Health Hum Rights. 2016;16:1-12. doi:10.1186/s12914-0160096-9

51. Alhassan RK, Nketiah-amponsah E, Spieker N, Arhinful DK, De Wit TFR. Perspectives of frontline health workers on Ghana' $\mathrm{s}$ National Health Insurance Scheme before and after community engagement interventions. BMC Health Serv Res. 2016;16:1-11. doi:10.1186/s12913-016-1438-y

52. Nsiah-boateng E, Aikins M, Asenso-boadi F. Value and service quality assessment of the national health insurance scheme in Ghana: evidence from Ashiedu Keteke District. Value Health Reg Issues. 2016;10C:7-13. doi:10.1016/j.vhri.2016.03.003

53. Witter S, Arhinful DK, Kusi A, Zakariah S. The experience of Ghana in implementing a user fee exemption policy to provide free delivery care. Reprod Health Matters. 2007;15:61-71. doi:10.1016/S0968-8080(07)30325-X

54. Fusheini A. The politico-economic challenges of Ghana's National Health Insurance Scheme Implementation. Int J Health Policy Manag. 2016;5:543-552. doi:10.15171/ijhpm.2016.47

55. Alhassan RK, Nketiah-Amponsah E, Akazili J, Spieker N, Arhinful DK, Rinke de Wit TF. Efficiency of private and public primary health facilities accredited by the National Health Insurance Authority in Ghana. Cost Eff Resour Alloc. 2015;13:1-14. doi:10.1186/s12962-015-0050-z

56. Alhassan F, Moses K, Kukurah J-D, Sakara A. Service quality in national health insurance scheme healthcare: a case study of WA municipal national health insurance scheme in the upper west region of Ghana. Dev Country Stud. 2014;4:108-123.

57. Yawson AE, Biritwum RB, Nimo PK. Effects of consumer and provider moral hazard at a municipal hospital out-patient department on Ghana's National Health Insurance Scheme. Ghana Med J. 2012;46:200-210.

58. Dalinjong PA, Laar AS. The national health insurance scheme: perceptions and experiences of health care providers and clients in two districts of Ghana. Health Econ Rev. 2012;2:1.

59. Dixon J, Tenkorang EY, Luginaah I. Ghana's National Health Insurance Scheme: a national level investigation of members' perceptions of service provision. BMC Int Health Hum Rights. 2013;13:1-10. doi:10.1186/1472-698X-13-35

60. Asundep NN, Carson AP, Archer C, et al. Determinants of access to antenatal care and birth outcomes in Kumasi, Ghana. $J$ Epidemiol Glob Health. 2013;3:279-288. doi:10.1016/j. jegh.2013.09.004

61. Piersson AD, Gorleku PN. Radiography assessment of availability, accessibility, and affordability of magnetic resonance imaging services in Ghana. Radiography. 2017;23:e75-9. doi:10.1016/j. radi. 2017.06 .002
62. Ayimbillah Atinga R. Healthcare quality under the National Health Insurance Scheme in Ghana: perspectives from premium holders. Int J Qual Reliab Manag. 2012;29:144-161. doi:10.11 08/02656711211199883

63. Lamptey AA, Nsiah-boateng E, Agyemang SA, Aikins M. National health insurance accreditation pattern among private healthcare providers in Ghana. Arch Public Health. 2017;75:1-7.

64. Agyemang KK, Adu-Gyamfi AB, Afrakoma M. Prospects and challenges of implementing a sustainable national health insurance scheme: the case of the Cape Coast Metropolis, Ghana. Dev Country Stud. 2013;3:140-149.

65. Andoh-Adjei FX, Van Der Wal R, Nsiah-Boateng E, Asante FA, Van Der Velden K, Spaan E. Does a provider payment method affect membership retention in a health insurance scheme? A mixed method study of Ghana's capitation payment for primary care. BMC Health Serv Res. 2018;18:1-12. doi:10.1186/s12913018-2859-6

66. Gyasi RM. Relationship between health insurance status and the pattern of traditional medicine utilisation in Ghana. EvidenceBased Complement Altern Med. 2015;2015:1-10. doi:10.1155/ 2015/717926

67. Andoh-Adjei FX, Cornelissen D, Asante FA, Spaan E, Van Der Velden K. Does capitation payment under national health insurance affect subscribers' trust in their primary care provider? A cross-sectional survey of insurance subscribers in Ghana. BMC Health Serv Res. 2016;16:1-11. doi:10.1186/s12913016-1622-0

68. Ibrahim A, O'Keefe A. Do infant birth outcomes vary among mothers with and without health insurance coverage in SubSaharan Africa? Findings from the National Health Insurance and Cash and Carry Eras in Ghana, West Africa. Int J Matern Child Health AIDS. 2014;2:200-208.

69. Ibrahim A, Maya ET, Donkor E, Agyepong IA, Adanu RM. Perinatal mortality among infants born during health user-fees (Cash \& Carry) and the national health insurance scheme (NHIS) eras in Ghana: a cross-sectional study. BMC Pregnancy Childbirth. 2016;16:1-8. doi:10.1186/s12884-016-1179-2

70. Lambon-Quayefio M, Owoo NS. Determinants and the impact of the National Health Insurance on neonatal mortality in Ghana. Health Econ Rev. 2017;7:1-16. doi:10.1186/s13561-017-0169-z

71. Strupat C, Klohn F. Crowding out of solidarity? Public health insurance versus informal transfer networks in Ghana. World Dev. 2018;104:212-221. doi:10.1016/j.worlddev.2017.1 1.004

72. Aryeetey GC, Westeneng J, Spaan E, Jehu-Appiah C, Agyepong IA, Baltussen R. Can health insurance protect against out-ofpocket and catastrophic expenditures and also support poverty reduction? Evidence from Ghana's National Health Insurance Scheme. Int J Equity Health. 2016;15:11. doi:10.1186/s12939016-0401-1

73. Sekyi S, Domanban PB. The effects of health insurance on outpatient utilization and healthcare expenditure in Ghana. (Special Issue: arts and social science.). Int J Humanit Soc Sci. 2012;2:40-49.

74. Aboagye DC, South J, Khan HT. Evaluation of community perspectives on national health insurance policy to health service service delivery in Ghana. Illness Cris Loss. 2017:1-16.

75. Mills A, Ataguba JE, Akazili J, et al. Equity in fi nancing and use of health care in Ghana, South Africa, and Tanzania: implications for paths to universal coverage. Lancet. 2012;380:126-133. doi:10.1016/S0140-6736(12)60357-2

76. Debpuur C, Dalaba MA, Chatio S, Adjuik M, Akweongo P. An exploration of moral hazard behaviors under the national health insurance scheme in Northern Ghana: a qualitative study. $B M C$ Health Serv Res. 2015;15(1):1-9. doi:10.1186/s12913-0151133-4 
77. Brinkerhoff DW, Bossert TJ. Health governance: principal-agent linkages and health system strengthening. Health Policy Plan. 2014;29:685-693. doi:10.1093/heapol/czs132

78. Agyepong IA, Adjei S. Public social policy development and implementation: a case study of the Ghana National Health Insurance scheme. Health Policy Plan. 2008;23:150-160. doi:10.1093/heapol/czn002

79. Fusheini A, Marnoch G, Gray AM, et al. Implementation Challenges of the National Health Insurance Scheme in Selected Districts in Ghana: evidence from the Field Implementation Challenges of the National Health Insurance Scheme in Selected Districts in Ghana: evidence from the Field. Int J Public Adm. 2017;40:416-426.

80. Fenny AP, Kusi A, Arhinful DK, Asante FA. Factors contributing to low uptake and renewal of health insurance: a qualitative study in Ghana. Glob Heal Res Policy. 2016;1:1-10.

81. Effah P, Appiah KO, Abor PA. Performance assessment of the Juaboso District Office of the National Health Insurance Authority. Value Health Reg Issues. 2016;10c:29-35. doi:10.1016/j.vhri.2016.06.002

82. Bandyopadhyay S, Kanji S, Wang L. The impact of rainfall and temperature variation on diarrheal prevalence in Sub-Saharan Africa. Appl Geogr. 2012;33:63-72. doi:10.1016/j.apgeog.2011.07.017

83. Adomah-afari A, Chandler JA. Social science \& medicine the role of government and community in the scaling up and sustainability of mutual health organisations: an exploratory study in Ghana. Soc Sci Med. 2018;207:25-37. doi:10.1016/j.socscimed.2018. 04.044

84. Agyepong AI, Nagai RA. We charge them; otherwise we cannot run the hospital " front line workers, clients and health financing policy implementation gaps in Ghana. Health Policy (New York). 2011;99:226-233. doi:10.1016/j.healthpol.2010.09.018

85. Wedam EA, Sanyare FN. Health care financing and sustainability: A study of current conceptual dialectics in Ghana. World Dev Perspect. 2017;5:47-55. doi:10.1016/j.wdp.2017.03.003

86. Seddoh A, Akor SA. Policy initiation and political levers in health policy: lessons from Ghanas health insurance. $B M C$ Public Health. 2012;12:1-11. doi:10.1186/1471-2458-12-S1-S10

87. National Health Insurance Authority. Holistic Assessment of 2017 Health Sector Programme of Work. Accra; 2018. Available from: https://www.moh.gov.gh/wp-content/uploads/ 2018/09/2017-Holistic-Assessment-Report_Final_09.08.2018. pdf. Accessed August 31, 2020.

88. Darko T How does government responsiveness come about? The politics of accountability in Ghana's National Health Insurance Scheme. Brighton; 2016. Available from: https://www.researchgate. net/publication/319356476_How_does_government_responsive ness_come_about_The_politics_of_accountability_in_Ghana's National_Health_Insurance_Scheme. Accessed April 27, 2020.

89. Ataguba JE, McIntyre D. The incidence of health financing in South Africa: findings from a recent data set. Health Econ Policy Law. 2017:1-24.

90. Gwarube S. Urgent Clarity Needed from Treasury Regarding NHI Funding. Politicsweb; 2019:1.

91. Hofman KJ, McGee S, Chalkidou K, Tantivess S, Culyer AJ. National health insurance in South Africa: relevance of a national priority-setting agency. South Afr Med J. 2015;105:739-740. doi:10.7196/SAMJnew.8584

92. Fin24. Mediclinic Says More Clarity Needed on NHI Bill; 2019:1.

93. Phillip X. South Africa's NHI Bill: Clarity Needed, and a Long Road Ahead | The Africa Report.com; 2019:1.

94. Mkhwanazi S. Mkhize Says Team to Fight Corruption in NHI IOL News; 2019:1.

95. Rispel LC, de Jager P, Fonn S. Exploring corruption in the South African health sector. Health Policy Plan. 2016;31:239-249. doi:10.1093/heapol/czv047
96. Mametja S NHI BILL background: historical phases of healthcare financing dialogue in SA. In: SAMA Conference 2018; South African Medical Association, Sun City; 2018:1-144.

97. Mabuza LH, Ogunbanjo GA, Hlabyago KE, Mogotsi M. Awareness of health care practitioners about the National Health Insurance in Tshwane District, South Africa Abstract. Open Public Health J. 2018;11:93-103. doi:10.2174/1874944501811010093

98. Amado L, Christofides N, Pieters R, Rusch J. National Health Insurance: a lofty ideal in need of cautious, planned implementation Introduction to the winning entry of the 2012 University of the Witwatersrand' s Medical Protection Society Bioethics Competition. South Afr J Bioeth Law. 2012;5:1-15.

99. Oladimeji O, Alabi A, Adeniyi OV. Awareness, Knowledge and Perception of The National Health Insurance Scheme (NHIS) Among Health Professionals in Mthatha General Hospital, Eastern Cape, South Africa. Open Public Health J. 2017;10:187-194. doi:10.2174/1874944501710010187

100. Motsepe A, Radiography B, Radiography P, Wolvaardt JE, Webb EM. Rapid assessment of two primary health clinics: are we ready for National Health Insurance? South Afr J Public Health Incorp Strength Health Syst. 2020;4(1):22-26. doi:10.7196/SHS.2020.v4.11.109

101. Tandwa L, Dhai A Public engagement in the development of the National Health Insurance: a study involving patients from a central hospital in South Africa; 2020. Available from: https:// europepmc.org/article/ppr/ppr135484. Accessed April 27, 2020.

102. Tandwa L, Dhai A (NHI): knowledge, awareness and participation of patients from the Internal Medicine Department at Charlotte Maxeke Johannesburg Academic Hospital in the NHI ... 2019. Available from: https://europepmc.org/article/ppr/ppr148266. Accessed April 27, 2020.

103. Molokomme VK, Seekoe E, Goon DT. The Perception of Professional Nurses About the Introduction of the National Health Insurance (NHI) in a Private Hospital in Gauteng, South Africa. Open Public Health J. 2018;11:234-242. doi:10.2174/ 1874944501811010234

104. South African Lancet National Commission. Confronting the right to ethical and accountable quality healthcare in South Africa. Pretoria; 2019. Available from: http://rhap.org.za/wp-con tent/uploads/2019/01/SA-Lancet-Report-Synopsis-South-Africa Confronting-the-Right-to-Ethical-Accountable-Healthcare.pdf. Accessed November 13, 2019.

105. Stellenberg E. Nursing failures fuel claims against private hospitals - stellenbosch study - Medical Brief. Med Br. 2018;1.

106. Kruk ME, Gage AD, Arsenault C, et al. The lancet global health commission high-quality health systems in the sustainable development goals era: time for a revolution. Lancet Glob Health. 2018;6:1196-1252. doi:10.1016/S2214-109X(18)30386-3

107. WHO, OECD, World bank. Delivering quality health services: a global imperative for universal health coverage; 2018. Available from: http://documents.worldbank.org/curated/en/ 482771530290792652/pdf/127816-REVISED-quality-joint-publi cation-July2018-Complete-vignettes-ebook-L.pdf. Accessed August 31, 2020.

108. National Academies of Sciences Engineering and Medicine. Crossing the Global Quality Chasm: Improving Health Care Worldwide. Washington, DC: The National Academies Press; 2018. doi:10.17226/25152

109. South African Medical Device Industry Association. SAMED Commentary on the National Health Insurance Draft Policy Paper. 2011.

110. Alhassan RK, Duku SO, Janssens W, et al. Comparison of perceived and technical healthcare quality in primary health facilities: implications for a sustainable National Health Insurance Scheme in Ghana. PLoS One. 2015;10(10):1-20. doi:10.1371/ journal.pone.0140109 
111. Rifkin SB. Examining the links between community participation and health outcomes: a review of the literature. Health Policy Plan. 2014;29:ii98-106. doi:10.1093/heapol/czu076

112. Barker M, Klopper H. Community participation in primary health care projects of the Muldersdrift health and development programme. Curationis. 2007;30(2):36-47. doi:10.4102/curationis.v30i2.1070

113. Haldane V, Chuah FLH, Srivastava A, et al. Community participation in health services development, implementation, and evaluation: A systematic review of empowerment, health, community, and process outcomes. PLoS One. 2019;14: e0216112. doi:10.1371/journal.pone.0216112

114. Meier BM, Pardue C, London L. Implementing community participation through legislative reform: a study of the policy framework for community participation in the Western Cape province of South Africa. BMC Int Health Hum Rights. 2012;12:15. doi:10.1186/1472-698X-12-15

115. Rispel LC, Blaauw D, Ditlopo P, White J. Human resources for health and universal health coverage: progress, complexities and contestations. South Afr Health Rev. 2018;1:13-22.

116. von Fintel D, Richter L. Intergenerational transfer of health inequalities: exploration of mechanisms in the Birth to Twenty cohort in South Africa. BMJ Glob Health. 2019;4(5):e001828. doi:10.1136/bmjgh-2019-001828

117. McLaren ZM, Ardington C, Leibbrandt M. Distance decay and persistent health care disparities in South Africa. BMC Health Serv Res. 2014;14:1-9. doi:10.1186/s12913-014-0541-1

118. National Health Insurance Authority. National Health Insurance Authority Annual Report. Accra; 2009.

119. National Health Insurance Authority. National Health Insurance Authority 2013 Annual Report; 2009.

120. Nsiah-Boateng E, Aikins M. Trends and characteristics of enrolment in the National Health Insurance Scheme in Ghana: a quantitative analysis of longitudinal data. Glob Heal Res Policy. 2018;3:1-10.

121. Wireko I, Béland D. Transnational actors and health care reform: why international organizations initially opposed, and later supported, social health insurance in Ghana. Int $J$ Soc Welf. 2017;26:405-415. doi:10.1111/ijsw.12257
122. Abrokwah SO, Callison K, Meyer DJ, Abrokwah SO, Callison K, Meyer DJ. Social health insurance and the use of formal and informal care in developing countries: evidence from Ghana' $\mathrm{s}$ National Health Insurance Scheme. J Dev Stud. 2017;1-15.

123. Abrokwah SO, Moser CM, Norton EC. The effect of social health insurance on prenatal care: the case of Ghana. Int J Heal Care Financ. 2014;14:385-406. doi:10.1007/s10754-014-9155-8

124. Abuosi AA, Domfeh KA, Abor JY, Nketiah-Amponsah E. Health insurance and quality of care: comparing perceptions of quality between insured and uninsured patients in Ghana's hospitals. Int $J$ Equity Health. 2016;15:1-12. doi:10.1186/s12939-016-0365-1

125. Apanga S, Chirawurah D, Kudiabor C, Adda J, Adoesom JA. Cost implication of irrational drug prescription under the national health insurance scheme in rural Ghana. Value Health. 2014;17: A19. doi:10.1016/j.jval.2014.03.122

126. Goudge J, Akazili J, Ataguba J, et al. Social solidarity and willingness to tolerate risk- and income-related cross-subsidies within health insurance: experiences from Ghana, Tanzania and South Africa. Health Policy Plan. 2012;27:i55-63. doi:10.1093/heapol/czs008

127. Nsiah-Boateng E, Asenso-Boadi F, Dsane-Selby L, et al. Reducing medical claims cost to Ghana's National Health Insurance scheme: a cross-sectional comparative assessment of the paper- and electronic-based claims reviews. BMC Health Serv Res. 2017;17:1-7. doi:10.1186/s12913-017-2054-1

128. Sackey FG, Amponsah PN. Willingness to accept capitation payment system under the Ghana National Health Insurance Policy: do income levels matter? Health Econ Rev. 2017;7:1-13. doi:10.1186/s13561-017-0175-1

129. Yilma Z, Van Kempen L, De Hoop T. A perverse 'net' effect? Health insurance and ex-ante moral hazard in Ghana. Soc Sci Med. 2012;75:138-147. doi:10.1016/j.socscimed.2012.02.035
Risk Management and Healthcare Policy

\section{Publish your work in this journal}

Risk Management and Healthcare Policy is an international, peerreviewed, open access journal focusing on all aspects of public health, policy, and preventative measures to promote good health and improve morbidity and mortality in the population. The journal welcomes submitted papers covering original research, basic science, clinical \& epidemiological studies, reviews and evaluations,

\section{Dovepress}

guidelines, expert opinion and commentary, case reports and extended reports. The manuscript management system is completely online and includes a very quick and fair peer-review system, which is all easy to use. Visit http://www.dovepress.com/testimonials.php to read real quotes from published authors. 